\title{
TENSILE STRENGTH OF NaCl ICE
}

\author{
By W. F. WEeks \\ (Department of Geology, Washington University, St. Louis 3o, Missouri)
}

Abstract. To resolve some of the factors causing strength variation in natural sea ice, fresh water and five different $\mathrm{NaCl}-\mathrm{H}_{2} \mathrm{O}$ solutions were frozen in a tank designed to simulate the one-dimensional cooling of natural bodies of water. The resulting ice was structurally similar to lake and sea ice. The salinity of the salt ice varied from $\mathrm{I} \%$ to $22 \%$. Tables of brine volumes and densities were computed for these salinities in the temperature range $0^{\circ}$ to $-35^{\circ} \mathrm{C}$. The ring-tensile strength $\sigma$ of fresh-water ice was found to be essentially temperature independent from $-10^{\circ}$ to $-30^{\circ} \mathrm{C}$., with an average value of $29.6 \pm 8.5 \mathrm{~kg}$. $\mathrm{cm}^{2}$ at $-10^{\circ} \mathrm{C}$. The strength of salt ice at temperatures above the eutectic point $\left(-21 \cdot 2^{\circ} \mathrm{C}\right.$. $)$ significantly decreases with brine volume $\nu ; \sigma=24.71-5.15 \nu^{\sharp}$. The $\sigma$-axis intercept of this line is comparable to the $\sigma$ values determined for fresh ice indicating that there is little, if any, difference in stress concentration between sea and lake ice as a result of the presence of brine pockets. The strength of ice containing $\mathrm{NaCl}$. ${ }_{2} \mathrm{H}_{2} \mathrm{O}$ is slightly less than the strength of fresh-water ice and is independent of the volume of solid salt and the ice temperature. No evidence was found for the existence of either phase or geometric hysteresis in NaCl ice. The strength of ice at sub-eutectic temperatures, however, is decreased appreciably if the ice has been subjected to temperatures above the eutectic point; this is the result of the redistribution of brine during the warm-temperature period. Short-term cooling produces an appreciable (20 per cent) decrease in strength, in fresh-water and $\mathrm{NaCl} \cdot 2 \mathrm{H}_{2} \mathrm{O}$ ice. The present results are compared with tests on natural sea ice and it is suggested that the strength of fresh-water ice is a limit which is approached but not exceeded by cold sea ice and that the reinforcement of brine pockets by $\mathrm{Na}_{2} \mathrm{SO}_{4} \cdot \mathrm{IOH}_{2} \mathrm{O}$ is either lacking or much less than previously assumed.

RÉsumÉ. Pour étudier quelques uns des facteurs qui provoquent une variation de résistance à la tension dans la glace de mer naturelle, on a congelé de l'eau douce et cinq solutions différentes de $\mathrm{Cl} \mathrm{Na}-\mathrm{H}_{2} \mathrm{O}$ dans un réservoir destiné à représenter le refroidissement suivant une dimension de masses naturelles d'eau. La glace résultante présentait une structure semblable à celle de la glace de lac et de mer. La salinité de la glace saumâtre variait de $\mathrm{I} \%$ a $22 \%$. Des tables du volume de la saumure et de la densité ont été calculées en fonction de la salinité dans l'intervalle de température o à $-35^{\circ} \mathrm{C}$. On a trouvé que la résistance "annulaire" à la tension $\sigma$ de la glace douce est essentiellement indépendante de la température de $-10^{\circ} \mathrm{C}$. à $-30^{\circ} \mathrm{C}$., avec une valeur moyenne de $29,6+8,5 \mathrm{~kg} / \mathrm{cm}^{2}$ à $-10^{\circ} \mathrm{C}$. La résistance à la tension de la glace saumâtre pour des températures supérieures au point eutectique $\left(-2 \mathrm{I}, 2^{\circ} \mathrm{C}\right)$ décroit de façon significative avec le volume de la saumure $\nu ; \sigma=24,7 \mathrm{I}-5, \mathrm{I} 5 \nu^{1}$. La valeur du point d'intersection de cette droite avec l'axe des $\sigma$ est comparable aux valeurs de $\sigma$ déterminées pour la glace douce, indiquant qu'il y a peu, sinon pas, de différence dans la concentration des tensions entre la glace de mer et la glace de lac résultant de la présence de poches de saumure. La résistance de la glace contenant $\mathrm{CINa} \cdot{ }_{2} \mathrm{H}_{2} \mathrm{O}$ est légèrement inférieure à celle de la glace d'eau douce et est indépendante du volume de sel solide et de la température de la glace. On n'a trouvé aucune évidence de l'existence d'hystérésis de phase ou géometrique dans la glace contenant du CINa. La résistance de la glace pour des températures sub-eutectiques décroit cependant de façon appréciable si la glace a été soumise à des températures au dessus du point eutectique par suite de la redistribution de la saumure durant la période chaude. Une courte période de refroidissement produit une décroissance appréciable de la résistance $\left(20 \%\right.$ ) dans la glace douce et la glace saumâtre $\left(\mathrm{ClNa}_{2} \mathrm{H}_{2} \mathrm{O}\right)$. On compare ces résultats avec les tests sur la glace de mer naturelle et l'on suggère que la résistance de la glace douce est une limite qui est approachée mais non dépassée dans le cas de la glace de mer froide et que le renforcement des poches de saumure par $\mathrm{SO}_{4} \mathrm{Na}_{2} \cdot \mathrm{IOH}_{2} \mathrm{O}$ est soit manquant soit inférieur aux estimations antérieures.

Zusammenfassung. Zur Untersuchung einiger der Faktoren, die Schwankungen in der Festigkeit natürlichen Meer-Eises bewirken, wurden frisches Wasser und 5 verschiedene $\mathrm{NaCl}-\mathrm{H}_{2} \mathrm{O}-\mathrm{Lösungen} \mathrm{in}$ einem Tank eingefroren, dessen Konstruktion die eindimensionale Abkühlung von natürlichen Wasserkörpern nachzuahmen gestattete. Das entstandene Eis war seiner Struktur nach dem See- und Meer-Eis ähnlich. Sein Salzgehalt schwankte von $1 \%$ bis $22 \%$. Bei diesen Salinitäten wurden Tabellen für Volumen und Dichte des Salzwassers im Temperaturbereich von o bis $-35^{\circ} \mathrm{C}$ errechnet. Die Ringzugfestigkeit $\sigma$ von Frischwassereis ergab sich im Bereich von -10 bis $-30^{\circ} \mathrm{C} \mathrm{im}$ wesentlichen als temperaturunabhängig mit einem Mittelwert von $29,6 \pm 8,5 \mathrm{~kg} / \mathrm{cm}^{2}$ bei $-10^{\circ} \mathrm{C}$. Die Festigkeit von Salzeis über dem eutektischen Punkt $\left(-2 \mathrm{I}, 2^{\circ} \mathrm{C}\right)$ nimmt beträchtlich mit dem Salzwasser-Volumen $\nu$ ab: $\sigma=24,7 \mathrm{I}-5, \mathrm{I} 5 \nu^{t}$. Der Vergleich des Ausgangswertes dieser Diagramm-Kurve auf der $\sigma$-Achse mit den gemessenen $\sigma$ Werten von Frischwassereis zeigt, dass der Unterschied in der Druckkonzentration zwischen Meer- und See-Eis, der durch Salzwasser-Taschen hervorgerufen wird,-wenn überhaupt vorhanden - nur gering ist. Die Festigkeit von Eis, das $\mathrm{NaCl} \cdot{ }_{2} \mathrm{H}_{2} \mathrm{O}$ enthält, ist etwas geringer als die von Frischwassereis und unabhängig vom Volumen des festen Salzes und von der Eistemperatur. Im NaCl-Eis wurden Anzeichen für das Auftreten von Phasen- oder Struktur-Hysterese gefunden. Allerdings nimmt die Festigkeit von Eis unter subeutektischen Punkt ausgesetzt war. Dies ist die Folge der Umlagerung von Salzwasser während der warmen Periode. Kurzzeitige Abkühlung bewirkt eine beachtliche $(20 \%)$ Abnahme der Festigkeit sowohl bei Frischwasserwie bei $\mathrm{NaCl} \cdot{ }_{2} \mathrm{H}_{2} \mathrm{O}$-Eis. Die vorliegenden Ergebnisse werden mit Versuchen an natürlichem Meer-Eis verglichen, was zu der Annahme führt, dass die Festigkeit von Frischwassereis einen Grenzwert darstellt, der von kaltem Meer-Eis zwar angenähert aber nicht überschritten wird und dass die Verstärkung von Salz-

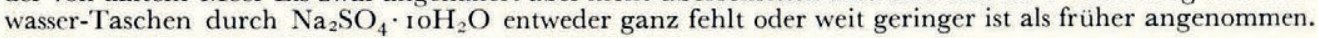


INTRODUCTION

During the last few years, there has been an increased interest in developing a rational explanation for the rather considerable variation in such bulk properties of sea ice as its strength, density, thermal conductivity, latent heat of melting, and coefficient of thermal expansion. Of these properties, sea ice strength has received by far the most attention for practical reasons. The first published investigation of sea-ice strength that was accompanied with sufficient temperature and salinity control to permit an analysis was made by Butkovich (1956). He performed in-place cantilever, ring-tensile, small beam flexural, and unconfined compression tests. Weeks and Anderson (1958) studied the variation in flexural strength of a large number of in-place cantilever beams from thin, relatively high salinity sea ice. In a concurrent paper, Anderson and Weeks (1958) attempted to explain the strength relations of young sea ice on the basis of the ice-brine geometry, as revealed by the study of thin sections, and the hypothesis that the strength of sea ice is equal to $\sigma_{p}(\mathrm{I}-\lambda) / k$, where $\sigma_{p}$ is the strength of so-called "pure" ice (ice with no brine pockets or air bubbles), measured by a similar testing procedure, $k$ is a stress-concentration factor introduced by the presence of brine pockets in the sea ice, and $(I-\lambda)$ is the reduction in effective cross-sectional area of the sea ice as a result of brine inclusions. This work has been extended by Assur (1958), who pointed out that the ratio of stress concentration in pure ice to that in sea ice should be considered instead of the absolute magnitude of the stress concentration in sea ice. Assur also demonstrated the importance of considering the presence of solid salts in the sea ice when computing brine volume tables and focused attention on the possible influence of the solid salts on the strength of the ice. Basing his work on the chemical determinations of Ringer (1906) and Thompson and Nelson (1956), Assur calculated a phase diagram for the freezing of standard sea-water and analyzed the variation of ring-tensile-strength data from a number of localities in both polar regions in the light of this phase diagram. His main hypotheses concerning the "entire spectrum" of strength relations in sea ice are shown in his figure 3 (Assur, I 958, p. I I I) and may be summarized as follows:

(a) At high temperatures (above $-8 \cdot 2^{\circ} \mathrm{C}$.), the strength of sea ice significantly decreases with an increase in $\nu^{\frac{1}{2}}$ where $\nu$ is the volume of the brine.

(b) At temperatures between $-8 \cdot 2^{\circ} \mathrm{C}$. and $-22 \cdot 9^{\circ} \mathrm{C}$., the presence of solid $\mathrm{Na}_{2} \mathrm{SO}_{4}$. $\mathrm{I}_{2} \mathrm{O}$ increases the strength of the ice by one-third.

(c) At temperatures below $-22 \cdot 9^{\circ} \mathrm{C}$., the presence of solid $\mathrm{NaCl} \cdot{ }_{2} \mathrm{H}_{2} \mathrm{O}$ causes sea ice to give strength values two or more times higher than fresh-water ice, if identical test procedures are used. This increase in strength is dependent upon the amount of solid salt in the ice.

(d) There is a strength hysteresis between normal one-season sea ice and old perennial pack ice, as the result of an increase in the $\mathrm{SO}_{4} / \mathrm{Cl}$ ratio in the ice caused by differential drainage of chloride-rich brine during periods when the ice temperature is between $-8 \cdot 2^{\circ} \mathrm{C}$. and $-22 \cdot 9^{\circ} \mathrm{C}$.

Assur (1958) has also discussed a number of alternative hypotheses. Unfortunately, the field data presently available are insufficient to indicate clearly which of these hypotheses best describes the strength variation of natural sea ice.

In addition, Butkovich (I959[b]) has observed an appreciable difference between ringtensile tests of sea ice of equivalent temperatures and salinities at Thule, Greenland, and Hopedale, Labrador. Two explanations which could be advanced to account for these differences are:

(a) The strength of sea ice of a given composition is strongly dependent upon the treatment and thermal history of the sample.

(b) The different thermal histories at Hopedale and Thule have produced significant changes in the ion ratios in the ice, thereby causing a change in the crystallization temperatures of the various solid salts. 
These problems could possibly be resolved by more extensive field testing. However, since the sea ice at a given field site at a specific time will usually have a rather restricted salinity and temperature range, tests at a large number of different field sites would be required to study a complete spectrum of temperatures and salinities. Therefore, it was decided to produce artificially an ice that is structurally similar to natural sea ice, but with a simple composition that makes the variation of physical properties with temperature and composition more amenable to study. The freezing of $\mathrm{NaCl}-\mathrm{H}_{2} \mathrm{O}$ solutions was chosen since $\mathrm{NaCl} \cdot{ }_{2} \mathrm{H}_{2} \mathrm{O}$ is the major salt found in natural sea ice and the phase diagram $\mathrm{NaCl}-\mathrm{H}_{2} \mathrm{O}$ has a simple eutectic point at $-2 \mathrm{I} \cdot 2^{\circ} \mathrm{C}$. Above the eutectic temperature, there is no solid salt in the ice; below this temperature, all the $\mathrm{NaCl}$ is solid as the phase $\mathrm{NaCl} \cdot{ }_{2} \mathrm{H}_{2} \mathrm{O}$. If the resulting ice is structurally similar to natural sea ice, it can then be tested to resolve some of the problems and theories as to the causes of the strength variation in sea ice.

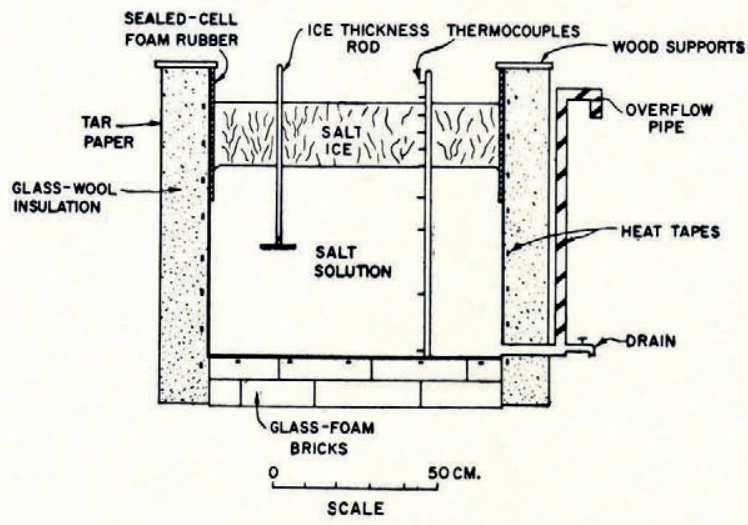

\section{EXPERIMENTATION}

Fig. I. Schematic diagram of the freezing tank

\section{Method of growing salt ice*}

An open-top cylindrical steel tank with a height and diameter of approximately $90 \mathrm{~cm}$. was modified by attaching an outlet to the bottom. The outlet was connected to a pressure release in order to prevent pressure build-up under the accreting ice. The inside of the tank was coated with a suitable corrosion preventing paint. A $\mathrm{I} \cdot 5 \mathrm{~cm}$. thick layer of sealed-cell foam rubber was cemented around the upper $30 \mathrm{~cm}$. of the tank to minimize stresses in the ice due to expansion. The outer surfaces of the tank were wrapped with a $2.5 \mathrm{~cm}$. layer of glass wool, and a series of heat tapes were stitched to the wool. A $15 \mathrm{~cm}$. thick layer of glass wool was placed on top of this and covered with a layer of tar paper. Two additional heat tapes were placed in a coil on the underside of the tank and the tank was placed on a $15 \mathrm{~cm}$. layer of insulating glass foam bricks. After installation of the tank in the cold room, the heat tapes were connected to a bank of "Powerstats" set at very low power to balance out lateral heat loss from the tank. The arrangement of heating and insulating elements effectively allowed one-dimensional cooling in the tank and simulated the heat flow conditions found on an ocean or a lake. A schematic diagram of this arrangement is shown in Figure $\mathrm{I}$.

A series of thermocouples installed on a vertical wooden rod was placed in the tank near its center so that temperatures were measured at 5 and $1 \mathrm{~cm}$. above the initial water surface and $\mathrm{o}, 5, \mathrm{IO}, \mathrm{I} 5,20,30,40,60$, and $80 \mathrm{~cm}$. below the surface. During a freezing run, the air, ice and water temperatures were read twice daily. During all freezing runs, a continuous

* The descriptive term "salt ice", refers to ice formed from the system under study (in this paper $\mathrm{NaCl}-\mathrm{H}_{2} \mathrm{O}$ ) while the term sea ice refers to ice formed by the freezing of natural sea-water. 
record of the general cold-room temperature $\left(-20^{\circ}\right.$ C. $)$ was maintained. As soon as the initial ice skim formed, a large table fan was used to blow cold air across the ice surface. The position and setting of this fan remained unchanged for all the runs. This breeze prevented air-temperature stratification and caused the upper ice surface temperature to approach the temperature of the cold room more closely. A freezing run normally took $1 \frac{1}{2}$ to 2 weeks to complete.

Ice thicknesses were measured using a hollow thin brass tube with a cross-bar at the end. A Nichrome heating element encased in glass fiber was placed inside the tube. This tube was then allowed to freeze into the ice with the cross-bar well below the lower ice surface. To measure the ice thickness a current was passed through the heating element until the brass tube melted free from the surrounding ice, the tube was raised until the cross-bar hit the lower ice surface, and the ice thickness determined.

When the ice of a given run had reached a thickness of 35 to $3^{8} \mathrm{~cm}$, , a rectangle $20 \times 30$ $\mathrm{cm}$. was marked on the ice surface in the middle of the tank. The ice surrounding this rectangle was then cut into $7.6 \mathrm{~cm}$. diameter vertical cores using a modified SIPRE corer (Bader, I 957). One core was immediately cut into a series of $2 \mathrm{~cm}$. horizontal layers so that the vertical salinity distribution in the ice could be determined. The other cores were immediately placed in storage at a temperature below the $\mathrm{NaCl}-\mathrm{H}_{2} \mathrm{O}$ eutectic point. This effectively prevented brine drainage from the ice. Approximately 20 cores were obtained. The rectangular center block was then cut free using a handsaw and placed in storage for thin-section studies. Salinities of the ice and water samples were determined by allowing the samples to come to thermal equilibrium at $+20^{\circ} \mathrm{C}$. and titrating the resulting solutions using a standard Mohr titration (Vogel, 1952, p. 904). When the sampling was completed, a wooden insulated cover was placed over the top of the tank and several immersion heaters were inserted through holes in the cover. As soon as the remaining scrap ice had melted, the tank was drained, rinsed, and refilled with fresh salt solution in preparation for another run.

\section{Strength test procedures}

There are many types of tests which have been or could be used to study the variation of sea-ice strength. The ring-tensile test procedure as described by Butkovich (1958) was chosen for several reasons. To characterize adequately the temperature dependence of the strength of ice of a relatively constant salinity, tests should be made at a minimum of five different temperatures: three above and at least two below the eutectic point. Since tests on apparently identical specimens of sea ice always show a large scatter (Butkovich; r956, I959[b]), a minimum of ten tests should be performed at any given temperature and ice salinity to characterize the strength distribution. This requires at least $5^{\circ}$ strength tests on ice from a single freezing run. Because of the limited size of the ice sample formed in the tank, only a small-scale ice strength test would satisfy these requirements. Assur (1958) and Butkovich (1956, 1959[b]) have based their conclusions regarding the strength variation in natural sea ice almost entirely on ring-tensile tests; similar test procedures would facilitate a direct comparison. In addition, since recent theoretical attempts to explain the variation in sea-ice strength (Anderson and Weeks, 1958; Assur, I 958) are concerned with failures in tension, the test used should approximate this condition. Also, ring-tensile test samples are relatively easy to prepare and the tests are rapid and simple to perform.

The samples were prepared for testing in the following manner. The stored cores were measured roughly and marked into $6 \mathrm{~cm}$. segments, noting the position of each segment below the upper surface of the ice sheet. The cores were cut along these marked lines with a bandsaw, and the length of each segment was measured in three different places to eliminate possible errors resulting from an irregular surface. The samples were weighed on a triple-beam balance and their densities computed. A $\frac{1}{2}$ in. $(1 \cdot 27 \mathrm{~cm}$.) co-axial hole was drilled in each specimen, which then was sealed in a polyethylene bag to prevent sublimation and placed in a box at storage temperature. 
The ring-tensile tests were performed using a Carver Hydraulic Press. The total load was determined with a Baldwin SR-4 (2,00o pound capacity) load cell which was attached to a recording potentiometer. The current input to the load cell was adjusted so that a full scale deflection of the potentiometer equaled I, Ooo pounds. The theory for the ring-tensile test was developed by Ripperger and Davids (1947) and its application to the testing of ice has been discussed by Butkovich ( $\left.195^{8}\right)$. The co-axially drilled cylinder is subjected to compression normal to its axis and the failure plane is directly beneath and parallel to the direction of application of the load.

The ring-tensile strength $\sigma$ can then be computed from

$$
\sigma=\frac{K P}{\pi r_{0} l}
$$

where $P$ is the load at failure, $l$ is the average length of the sample and $r_{\mathrm{o}}$ is the outer radius of the sample, in this case $3.8 \mathrm{~cm}$. The stress concentration factor $K$ is determined by the ratio $r_{i} / r_{\mathrm{o}}$ where $r_{i}$ is the radius of the co-axial hole. Holes of different sizes have been used by various investigators and the effect of this change on strength results for glacier ice has bcen studied by Butkovich (I959[a]) who concluded that no difference in ring-tensile strength resulted between holes of less than $2.5 \mathrm{~cm}$. in diameter. The author used the $\frac{1}{2}$ inch diameter hole primarily to increase the failure load in the ice with the higher brine volumes.

Since the ring-tensile test is designed specifically for testing a truly elastic material, the load was applied at a rate greater than $\mathrm{I} \mathrm{kg} . / \mathrm{cm} .{ }^{2} \mathrm{sec}$. This rate is apparently high enough to minimize any plastic yielding (Jellinek, r958). Within the limit of this approximation, the ring tests should give the tensile strength of a brittle substance.

Ring-tensile tests give values that are consistently higher than tests made either in flexure or in direct tension. Although there is a large scatter in the test values from a given group of ring-tensile tests, ring tests apparently give more consistent results than small-beam flexuralstrength tests, which are the only other small-sample tests that have been used extensively on sea ice (Assur, personal communication). The lack of direct tensile-test procedures is probably due to the difficulty of producing a firm bond between sea ice and metal at warm temperatures, where there is an appreciable amount of brine in the ice.

It is important to emphasize that the strength values presented in this paper should not be used directly in plate equations for the purpose of predicting trafficability criteria.

\section{Bulk Properties of Salt Ice}

\section{Phase Relations}

In natural sea ice, the phase relations are quite complex with varying amounts of brine, solid salt mixtures, and ice coexisting at different temperatures below the freezing point. Only in the narrow range between the initial freezing point of sea-water $\left(c .-\mathrm{I} \cdot 8^{\circ} \mathrm{C}\right.$. $)$ and $-2 \cdot 2^{\circ} \mathrm{C}$. where $\mathrm{CaCO}_{3} \cdot 6 \mathrm{H}_{2} \mathrm{O}$ begins to crystallize can sea ice be considered as a true brine-ice system. As the temperature is lowered, the amount of brine in the ice decreases and the amount of solid salt increases. Even at $-54^{\circ} \mathrm{C}$., there is still a small amount of brine remaining in the ice (Assur, 1958).

$\mathrm{NaCl}$ ice offers a rather simplified model of natural sea ice and effectively allows one to test the strength variation of the two extreme cases of natural sea ice; an ice-brine system and an ice-solid salt system. The dividing temperature between these two systems is the eutectic temperature of $-2 \mathrm{I} \cdot 2^{\circ} \mathrm{C}$. The phase diagram for the high $\mathrm{H}_{2} \mathrm{O}$ portion of the system $\mathrm{NaCl}-$ $\mathrm{H}_{2} \mathrm{O}$ is shown in Figure 2 (Landolt and Börnstein, I936).

The brine content by volume for air-free $\mathrm{NaCl}$ ice at temperatures above $-2 \mathrm{I} \cdot 2^{\circ} \mathrm{C}$. was computed by using the following relations. In $m$ grams of salt ice of salinity $S_{i}$ parts per thousand $(\%)$, there are $n$ grams of brine of salinity $S_{b}$ parts per thousand (Malmgren, I927, p. 67).

$$
n=m S_{i} / S_{b}
$$


The value of $S_{b}$ in equilibrium with ice is fixed at any given temperature by the relations shown on the $\mathrm{NaCl}-\mathrm{H}_{2} \mathrm{O}$ phase diagram. $\mathrm{NaCl}$ brine tables were used in determining the relation between the freezing point and concentration of the brine. Since there are also $m$ $\left(\mathrm{I}-S_{i} / S_{b}\right)$ grams of ice at a given temperature, the brine content by volume $\nu$ in parts per thousand of brine is

$$
\nu=1000\left\{\frac{S_{i} / \rho_{b} S_{b}}{S_{i} / \rho_{b} S_{b}+\left(\mathrm{I}-S_{i} / S_{b}\right) / \rho_{i}}\right\}
$$

where $\rho_{i}$ and $\rho_{b}$ are the densities of the pure ice and brine respectively at the given temperatures. The variation of $\rho_{i}$ with temperature was computed using a coefficient of cubical expansion of $\mathrm{I} \cdot 6 \times \mathrm{IO}^{-4} /{ }^{\circ} \mathrm{C}$. (Butkovich, 1955). The $\nu$ relation was programmed for a digital computer and brine volume tables were generated in the ice salinity range of o to $30 \%$ at

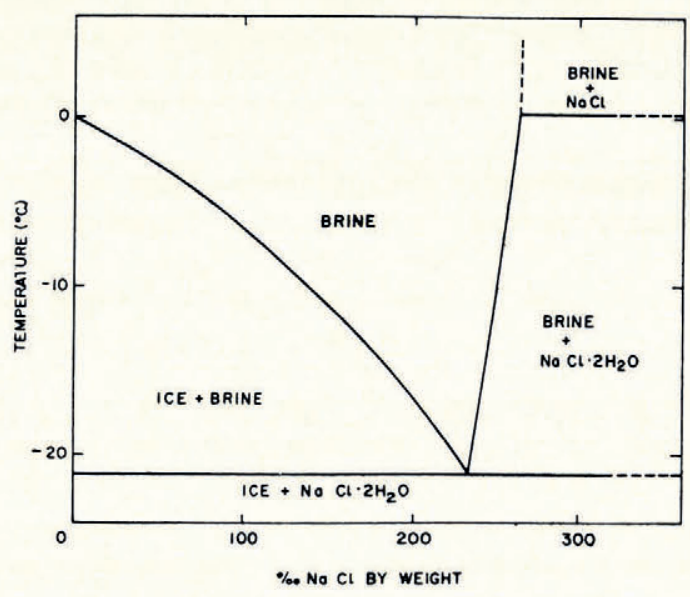

Fig. 2. A portion of the phase diagram $\mathrm{NaCl}-\mathrm{H}_{2} \mathrm{O}$

temperatures of $-5^{\circ},-10^{\circ}$, and $-20^{\circ} \mathrm{C}$. All strength tests at temperatures higher than the eutectic were conducted at these three temperatures. The brine volume of a $1 \%$ salinity ice as a function of ice temperature is given in Figure 3. A good approximation of the brine volume of salt ice of any salinity can be obtained from this figure simply by multiplying the values for $1 \%$ by the observed salinity of the ice. The error caused by using this figure instead of the more accurate values used in this paper is 3.3 per cent for a $20 \%$ salt ice at $-5^{\circ} \mathrm{C}$. Considering the large scatter in the ring-tensile results, the error introduced in the final analysis by using the condensed brine volume table would not be appreciable for most purposes. This 3 per cent error can probably also be considered as a reasonable estimate of the maximum error resulting from the use of the table prepared by Assur (1958) for the brine volume of natural sea ice.

At temperatures below $-2 \mathrm{I} \cdot 2^{\circ} \mathrm{C}$., where $\mathrm{NaCl} \cdot{ }_{2} \mathrm{H}_{2} \mathrm{O}$ crystallizes, a different relation must be used to compute the fraction of $\mathrm{NaCl} \cdot{ }_{2} \mathrm{H}_{2} \mathrm{O}$ by volume existing in the ice. Since titration gives the salinity of the ice in parts per thousand of $\mathrm{NaCl}$ by weight, this figure must be converted to the volume of $\mathrm{NaCl} \cdot{ }_{2} \mathrm{H}_{2} \mathrm{O}, v\left(\mathrm{NaCl} \cdot{ }_{2} \mathrm{H}_{2} \mathrm{O}\right)$ per kilogram of ice using the relation

$$
v\left(\mathrm{NaCl} \cdot{ }_{2} \mathrm{H}_{2} \mathrm{O}\right)=\frac{M\left(\mathrm{NaCl} \cdot{ }_{2} \mathrm{H}_{2} \mathrm{O}\right) S_{i}}{M(\mathrm{NaCl}) \rho\left(\mathrm{NaCl} \cdot{ }_{2} \mathrm{H}_{2} \mathrm{O}\right)} .
$$


Therefore, the parts per thousand by volume of solid salt in the ice, $V\left(\mathrm{NaCl} \cdot{ }_{2} \mathrm{H}_{2} \mathrm{O}\right)$ is given by the equation

$$
V\left(\mathrm{NaCl} \cdot{ }_{2} \mathrm{H}_{2} \mathrm{O}\right)=\frac{v\left(\mathrm{NaCl} \cdot{ }_{2} \mathrm{H}_{2} \mathrm{O}\right) \times \mathrm{IO}^{3}}{v\left(\mathrm{NaCl} \cdot{ }_{2} \mathrm{H}_{2} \mathrm{O}\right)+\frac{\mathrm{I}}{\rho_{i}}\left[10^{3}-\frac{M\left(\mathrm{NaCl} \cdot{ }_{2} \mathrm{H}_{2} \mathrm{O}\right) S_{i}}{M(\mathrm{NaCl})}\right]}
$$

where $S_{i}$ is the salinity of the ice in grams of $\mathrm{NaCl}$ per kilogram of solution and $M$ and $\rho$ are the gram molecular weights and densities in $\mathrm{g} . / \mathrm{cm} .{ }^{3}$ of the substances specified in the parentheses. A density of ${ }_{\mathrm{I}} \cdot 630 \mathrm{~g} \cdot / \mathrm{cm} .{ }^{3}$ was used for $\rho\left(\mathrm{NaCl} \cdot{ }_{2} \mathrm{H}_{2} \mathrm{O}\right)$ at all temperatures (Adams and Gibson, 1930), since neither the coefficient of thermal expansion nor the structure

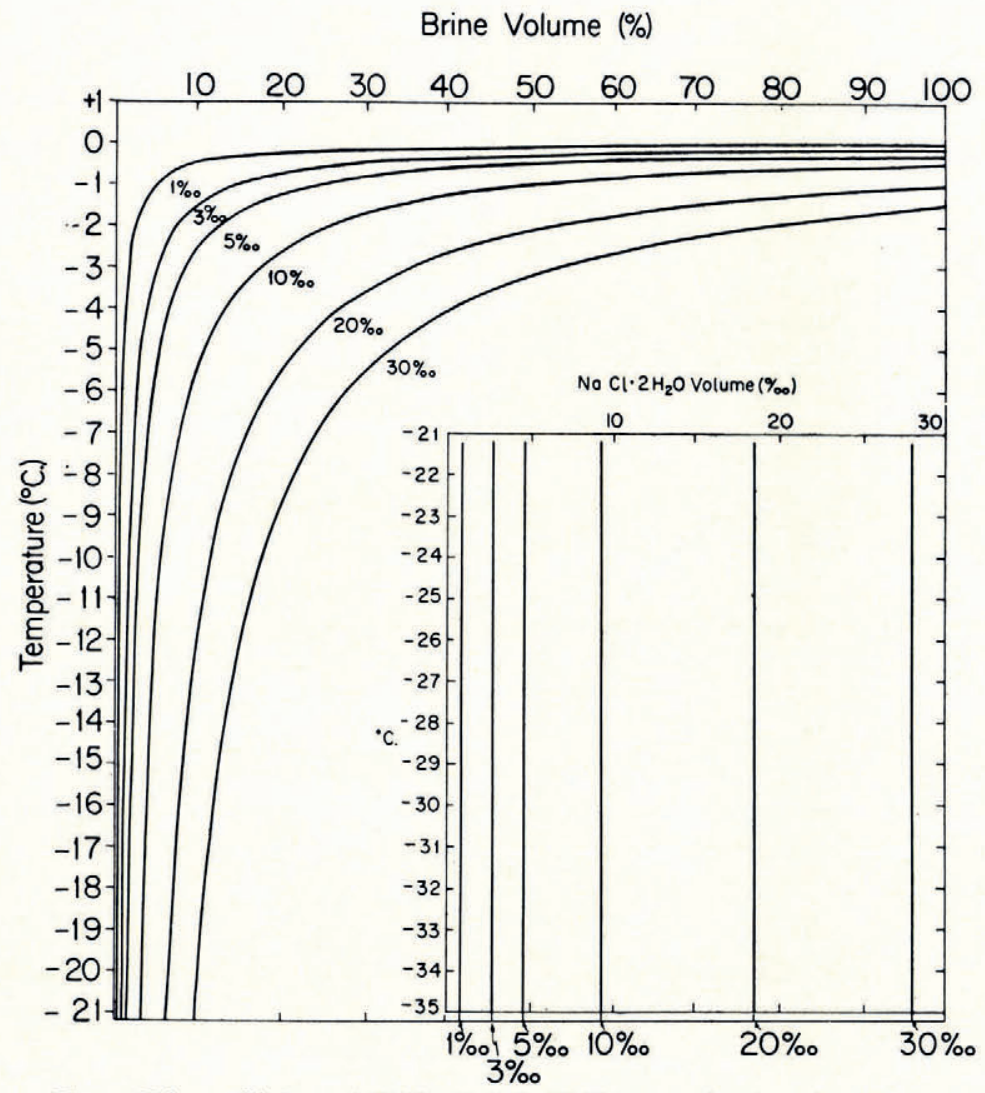

Fig. 3. Volume of brine and $\mathrm{NaCl} \cdot 2 \mathrm{H}_{2} \mathrm{O}$ in $\mathrm{NaCl}$ ice as a function of temperature

of this compound appears to be known. The $\mathrm{NaCl} \cdot{ }_{2} \mathrm{H}_{2} \mathrm{O}$ volume in a $\mathrm{I} \%$ ice as a function of temperature is given in Figure 3.

Density and air content

The density of air-free salt ice as a function of temperature and salinity at temperatures above the eutectic point is presented in Figure 4 . These values were computed using the relationship

$$
\rho=\frac{\mathrm{I}}{S_{i} / \rho_{b} S_{b}+\left(\mathrm{I}-S_{i} / S_{b}\right) / \rho_{i}} .
$$

Examination of Figure 4 shows that lower salinity ice goes through a density minimum above the eutectic point as the temperature decreases. This minimum is the result of the density 
decrease associated with the water-ice phase transition opposing the general density increase of both the ice and brine with decreasing temperature. That similar relations should exist in natural sea ice has been shown by Zubov (1945, p. 360) and in more detail by Anderson ( 1960$)$. There is also a slight discontinuity in the density at $-2 \mathrm{I} \cdot \mathrm{I}^{\circ} \mathrm{C}$., caused by the crystallization of ice and $\mathrm{NaCl} \cdot{ }_{2} \mathrm{H}_{2} \mathrm{O}$ at the eutectic point. At temperatures below the eutectic point, the density of salt ice slowly increases and was computed from

$$
\rho=\frac{\mathrm{IO}^{3}}{V\left(\mathrm{NaCl} \cdot{ }_{2} \mathrm{H}_{2} \mathrm{O}\right)+\frac{\mathrm{I}}{\rho_{i}}\left[1 \mathrm{IO}^{3}-\frac{M\left(\mathrm{NaCl} \cdot{ }_{2} \mathrm{H}_{2} \mathrm{O}\right) S_{i}}{M(\mathrm{NaCl})}\right]}
$$

These values are also shown in Figure 4.

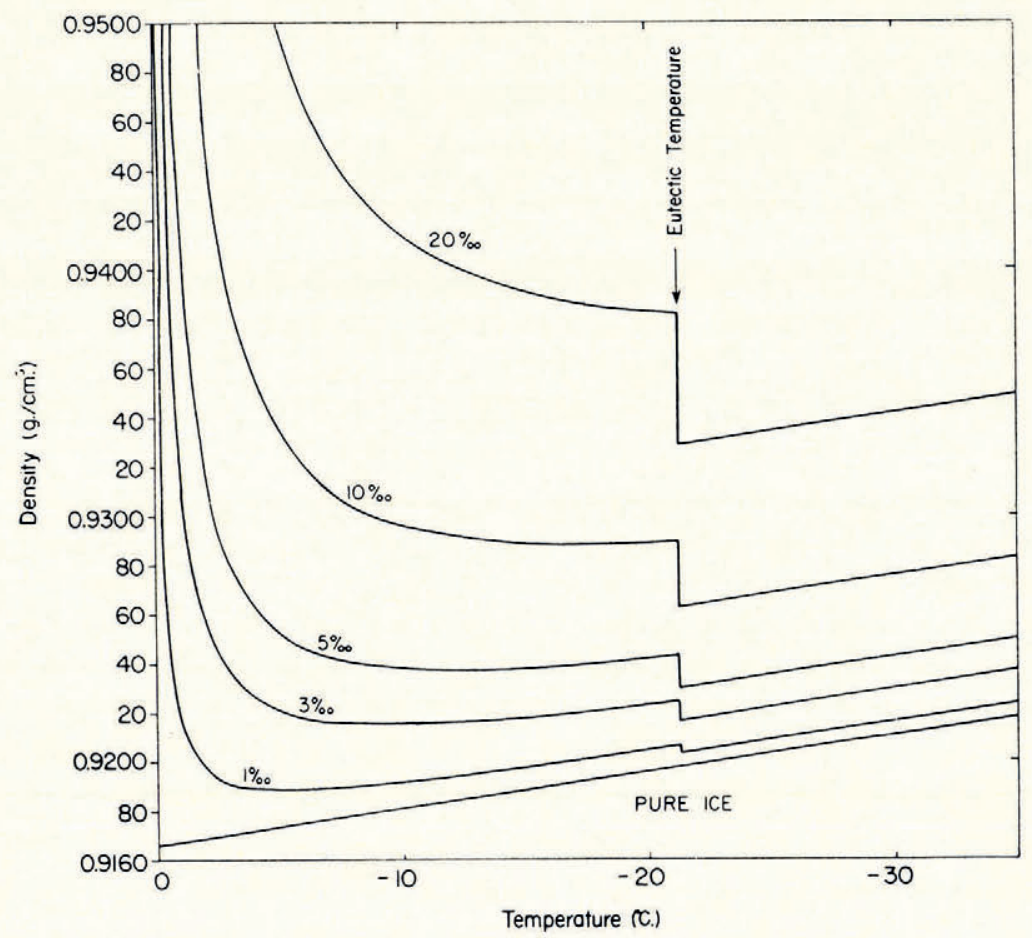

Fig. 4. Density of an air-free $\mathrm{NaCl}$ ice as a function of temperature and salinity

The proportion of the sample by volume that is air was then determined using the relation

$$
V_{a}=\frac{\rho_{i(l)}-\rho_{i(o)}}{\rho_{i(t)}}
$$

where $\rho_{i(o)}$ is the observed density of the salt ice in $\mathrm{g} . / \mathrm{cm} .{ }^{3}$ and $\rho_{i(t)}$ is the theoretical density of air-free salt ice with a salinity, temperature and internal pressure identical to that of the sample.

As discussed earlier, the observed densities $\rho_{i(o)}$ of the samples were obtained by weighing a segment of the cylindrical ice core. The length of this segment was measured accurately, but the diameter of the core was assumed to equal the inside diameter of the corer $(7 \cdot 62 \mathrm{~cm}$.). Although the core could not have a diameter greater than $7.62 \mathrm{~cm}$. it could easily have a diameter less than $7.62 \mathrm{~cm}$. as a result of uneven drilling or gouges in the core, i.e. the computed density can be less, but should not be more, than the real density. That this is occasionally not the case can be seen by comparing the computed densities with the theoretical densities 
for air-free salt ice. In several cases, the measured densities are higher than the theoretical densities for the air-free ice. These anomalous values apparently result from slush formed during the coring process freezing to the ice core.

\section{Strength Results}

Seven different freezing runs were completed on solutions in the system $\mathrm{NaCl}-\mathrm{H}_{2} \mathrm{O}$. The initial compositions of the solutions and the average salinity of the resulting salt ice in each run are as follows: Runs I and VII, solution $0 \% \mathrm{NaCl}$, ice $\% \% \mathrm{NaCl}$; Run II, solution $4 \cdot 46 \% \mathrm{NaCl}$, ice $\mathrm{I} \cdot 73 \% \mathrm{NaCl}$; Run III, solution $9 \cdot 77 \%$ o $\mathrm{NaCl}$, ice $2 \cdot 83 \% \mathrm{NaCl}$; Run IV, solution $20 \cdot 54 \%$ NaCl, ice $5 \cdot 16 \%$ NaCl; Run V, solution $29 \cdot 51 \%$ NaCl,

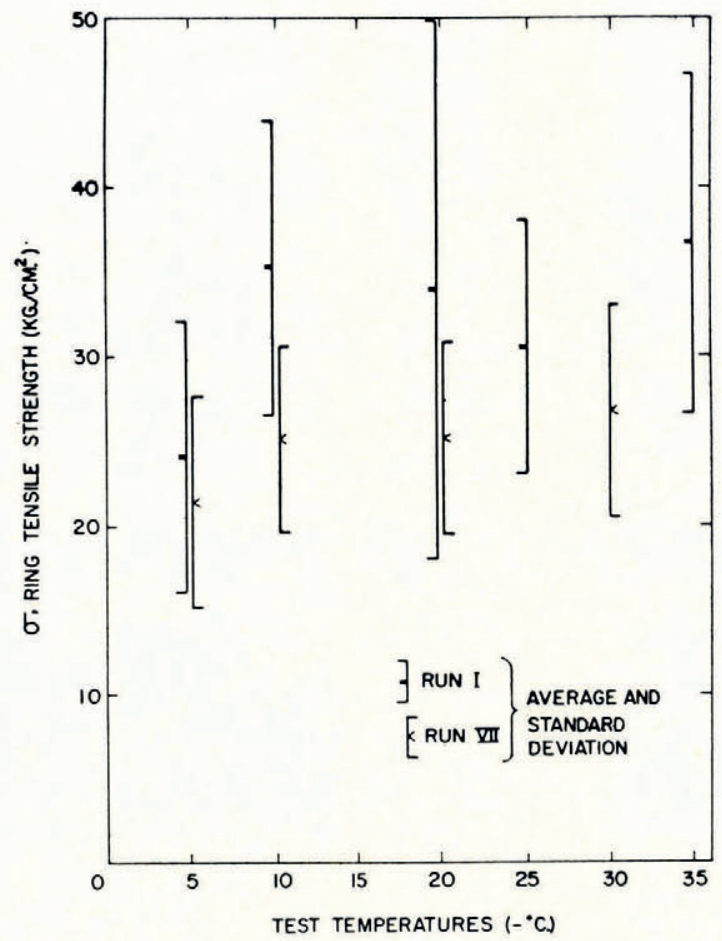

Fig. 5. Ring-tensile strength of fresh-water ice as a function of temperature

ice $7 \cdot 52 \%$ NaCl and Run VI, solution $70 \cdot 13 \% \mathrm{NaCl}$, ice ${ }_{15} \cdot 73 \%$ NaCl. These solution compositions were chosen to simulate the salinities that would be expected in normal lake and sea-water, and the intermediate salinities characteristic of bodies of brackish water such as the Black and Baltic Seas. In addition, Run VI provides information on higher salinity ice, thereby establishing some control for extrapolating existing field data to higher salinities.

Strength of fresh-water ice

Both of the "pure" ice freezing runs used Lake Michigan tap water. The resulting ice from both Runs I and VII was coarsely crystalline with the majority of the $c$-axes normal to the plane of the freezing surface. The ice produced in both runs was extremely clear and contained no visible flaws or air bubbles. This is in contrast with natural fresh-water ice, which may contain a large number of small cracks and air bubbles.

The ring-tensile strengths and standard deviations of the ice from Runs I and VII are plotted against test temperature in Figure 5. A least-squares straight line to all the data $\sigma=$ 
$23.94-0.27 T$ indicates a slight positive slope with a temperature coefficient of 0.0II3. The main factor contributing to this slope is the appreciable decrease in the $\sigma$ values at $-5^{\circ} \mathrm{C}$. If these $-5^{\circ} \mathrm{C}$. values are disregarded, the least squares equation is $\sigma=28 \cdot 02-$ o. II $T$ with a temperature coefficient of 0.0039 indicating that the ring-tensile strength is essentially temperature independent in the range $T=-10^{\circ}$ to $-35^{\circ} \mathrm{C}$. It can be seen that Runs I and VII show similar trends; a relative independence of strength of temperature in the range $-10^{\circ}$ to $-35^{\circ} \mathrm{C}$. and a slightly lower strength value at $-5^{\circ} \mathrm{C}$. There is, however, an appreciable and consistent difference between the $\sigma$ values from the different runs. An explanation of these differences is presented in the discusson of the effects of short-term cooling. The grand average of Run I is $32 \cdot 15 \pm 10 \cdot 95 \mathrm{~kg} . / \mathrm{cm} .^{2}$, while the average for Run VII is $24 \cdot 53 \pm 6 \cdot 18 \mathrm{~kg} . / \mathrm{cm} .{ }^{2}$. The overall average for both runs is $27 \cdot 56 \pm 9 \cdot 18 \mathrm{~kg} . / \mathrm{cm} .{ }^{2}$. The strength values at a given temperature of all the fresh-water ice tests are characterized by a very large scatter, which gives a natural variability (standard deviation divided by the arithmetic average) of $0.3 \mathrm{I}$ and 0.24 for Runs I and VII respectively.

Previous measurements of the tensile strength of ice are quite rare. Table I presents a

Table I. Comparison of Tensile and Flexural Strength Values for Fresh-Water Ice

\begin{tabular}{|c|c|c|c|c|c|}
\hline $\begin{array}{c}\text { Test } \\
\text { procedure }\end{array}$ & $\begin{array}{l}\text { Ice } \\
\text { type }\end{array}$ & $\begin{array}{l}\text { Orientation of } \\
\text { tensile stresses }\end{array}$ & $\begin{array}{l}\text { Strength } \\
\mathrm{kg} \cdot / \mathrm{cm} .^{2}\end{array}$ & $\begin{array}{c}\text { Temperature } \\
\text { range } \\
{ }^{\circ} \mathrm{C} .\end{array}$ & Investigator \\
\hline $\begin{array}{l}\text { direct } \\
\text { tension }\end{array}$ & $\begin{array}{l}\text { commercial } \\
\text { ice }\end{array}$ & & $14 \cdot 6$ to $18 \cdot 7$ & -5 to $-4^{\circ}$ & Butkovich (1954) \\
\hline flexure & $\begin{array}{l}\text { Lake Michigan ice } \\
\text { and artificial ice }\end{array}$ & $\begin{array}{l}\text { perpendicular to } \\
\text { direction of grain } \\
\text { elongation and op- } \\
\text { tic axes }\end{array}$ & $12 \cdot 3$ to $18 \cdot 3$ & o to -23 & $\begin{array}{l}\text { Wilson and } \\
\text { Horeth (1948) }\end{array}$ \\
\hline Hexure & $\begin{array}{l}\text { lake ice, Shippe- } \\
\text { gan, New Bruns- } \\
\text { wick }\end{array}$ & $\begin{array}{l}\text { parallel to direc- } \\
\text { tion of grain elon- } \\
\text { gation }\end{array}$ & 35 to 70 & -22 & $\begin{array}{l}\text { Pounder and } \\
\text { Little (1959) }\end{array}$ \\
\hline flexure & $\begin{array}{l}\text { Lake Superior } \\
\text { ice }\end{array}$ & $\begin{array}{l}\text { perpendicular to } \\
\text { direction of grain } \\
\text { elongation }\end{array}$ & $12 \cdot 2$ to $16 \cdot 4$ & -5 to -20 & Hitch (1959) \\
\hline flexure & $\begin{array}{l}\text { lake ice Garrison } \\
\text { Reservoir, North } \\
\text { Dakota }\end{array}$ & $\begin{array}{l}\text { perpendicular to } \\
\text { direction of grain } \\
\text { elongation }\end{array}$ & $19 \cdot 6$ & -7 to $-15 \cdot 2$ & $\begin{array}{l}\text { Frankenstein } \\
\quad(1959)\end{array}$ \\
\hline Hexure & $\begin{array}{l}\text { lake ice, Garrison } \\
\text { Reservoir, North } \\
\text { Dakota, and } \\
\text { Flambeau River, } \\
\text { Wisconsin }\end{array}$ & $\begin{array}{l}\text { perpendicular to } \\
\text { direction of grain } \\
\text { elongation }\end{array}$ & $16 \cdot 5$ & $0 \cdot 0$ to $-4 \cdot 0$ & $\begin{array}{l}\text { Frankenstein } \\
\quad(1959)\end{array}$ \\
\hline ring-tensile & $\begin{array}{l}\text { glacier ice, } \\
\text { TUTO Tunnel, } \\
\text { Greenland }\end{array}$ & $\begin{array}{l}\text { perpendicular to } \\
\text { direction of } c \text { - } \\
\text { axis }\end{array}$ & $26 \cdot 0$ to $30 \cdot 2$ & -5 & $\begin{array}{l}\text { Butkovich } \\
\quad(\text { I } 959[\mathrm{a}])\end{array}$ \\
\hline ring-tensile & lake ice & & $>{ } 5$ & & Assur (1958) \\
\hline
\end{tabular}

summary of recent values from the literature. Of these, only Assur (1958) mentions the results of ring-tensile tests on lake ice, but without giving detailed data. In view of the facts that, in other types of ice, ring-tensile tests consistently yield higher values than either flexural or direct tension tests (Butkovich, 1958) and that other investigators appear to find that the tensile and flexural strength of lake and artificial ice lies in the range 12 to $20 \mathrm{~kg} . / \mathrm{cm} .{ }^{2}$ at temperatures between $0^{\circ}$ and $-40^{\circ} \mathrm{C}$., Assur's originally reported value of somewhat above I $5 \mathrm{~kg} . / \mathrm{cm} .^{2}$ appears to be too low. During later tests Assur has found average values more consistently above $20 \mathrm{~kg}$. $/ \mathrm{cm}^{2}{ }^{2}$, which compare favorably with the present results. 
It is interesting to note that the author's results are quite similar to the ring-tensile strengths obtained by Butkovich (1959[a]) on glacier ice from the TUTO tunnel, Thule, Greenland. The ice studied by Butkovich was generally equi-granular with an average grain diameter in the range of 5 to $7 \mathrm{~mm}$. Although many of these samples had a rather strong preferred orientation with the $c$-axes vertical, Butkovich found no difference between the ring-tensile strengths of samples from vertical and horizontal cores.

\section{Strength of $\mathrm{NaCl}$ ice as a function of brine volume}

Anderson and Weeks (1958) discussed two different specific models of the ice-brine geometry in attempting to account for the strength variation observed in sea ice. These models were based on observed changes in the shapes of the brine pockets as a function of temperature and can be described briefly as constant-width and cylindrical brine pocket models. If these models were to hold, the strength $\sigma$ should be a linear function $f_{l}$ of $\nu$ and

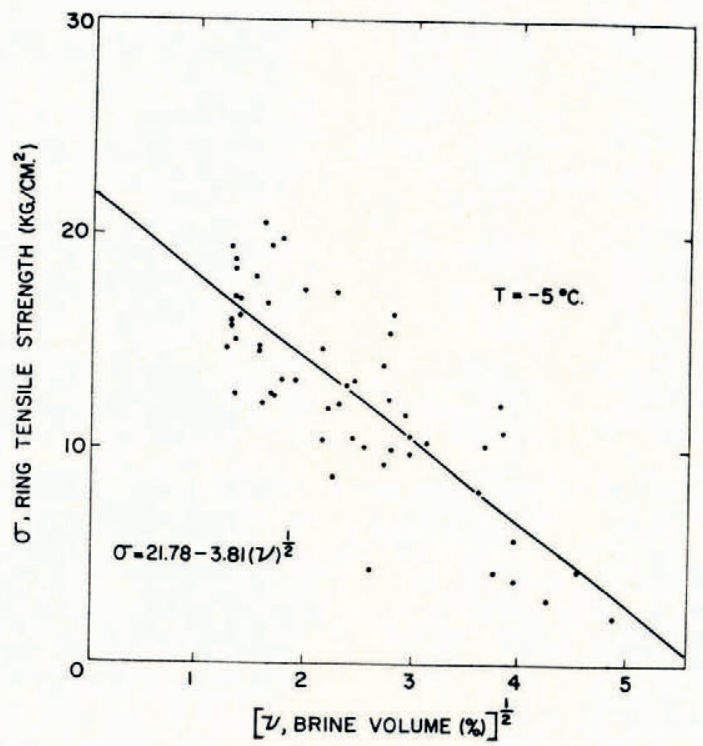

Fig. 6. Ring-tensile strength of $\mathrm{NaCl}$ ice vs $\nu^{\natural}, \mathrm{T}=-5^{\circ} \mathrm{C}$.

$\nu^{\frac{1}{2}}$ respectively. Assur (1958) gave a general geometric theory for such models and concluded that the three simplest conditions that might control the change in brine pocket shape with temperature are: (a) geometric similarity along a line, $\sigma=f_{l}(v)$; (b) geometric similarity in a plane, $\sigma=f_{l}\left(\nu^{\frac{1}{2}}\right)$; and (c) geometric similarity in a space, $\sigma=f_{l}\left(\nu^{*}\right)$. Which of these models, if any, most adequately describes the relations in sea or salt ice can be tested either by petrographic measurements of changes in brine pocket shapes as a function of temperature, or by determining which of the above relations most closely fits the actual strength test results. Assur has used $\sigma=f_{l}\left(\nu^{\frac{1}{2}}\right)$ down to $-22 \cdot 9^{\circ} \mathrm{C}$. where $\mathrm{NaCl} \cdot{ }_{2} \mathrm{H}_{2} \mathrm{O}$ precipitates.

Test results were grouped according to their test temperatures $\left(-5^{\circ},-\mathrm{IO}^{\circ}\right.$ and $-20^{\circ} \mathrm{C}$. $)$ and plotted against various brine volume parameters. This grouping was used to nullify any temperature influence on the strength of the ice portion of the brine-ice system. Therefore, observed strength variations should be the result only of the variable brine volume and of changes in the geometry of the brine pockets.

A plot of $\sigma$ against $\nu^{\frac{1}{2}}$ at $-5^{\circ} \mathrm{C}$. is shown in Figure 6. The $-10^{\circ}$ and $-20^{\circ}$ C. measurements 
are similar, showing a large scatter. The correlation coefficient, $r$, was computed for the variation of $\sigma$ with $\nu, \nu^{\frac{1}{2}}$ and $\nu^{\frac{2}{3}}$ at $-5^{\circ},-10^{\circ}$, and $-20^{\circ} \mathrm{C}$. To test for significant differences between these correlation coefficients, the statistic $z$ was computed; $z=\frac{1}{2} \ln \left(\frac{\mathrm{I}+r}{\mathrm{I}-r}\right)$.

Then the $t$-number for the difference was determined using $t=\frac{\left|z_{k}-z_{\frac{1}{2}}\right|}{\{2 /(n-3)\}^{\frac{1}{2}}}$

where $n$ is the number of tests (Goulden, I952, p. 457). The $t$-numbers, in all cases, are insignificant, indicating that the presently available data do not permit a choice between the different brine volume exponents. However, to facilitate comparison with previous work on natural sea ice, it was decided to utilize plots of $\sigma v s v^{\frac{1}{2}}$ in the following portions of this paper.

Figure 16 shows the average strength values for each test group plotted against the average value of $\nu^{\frac{1}{2}}$ for the group. There is no systematic deviation from the linear relation with

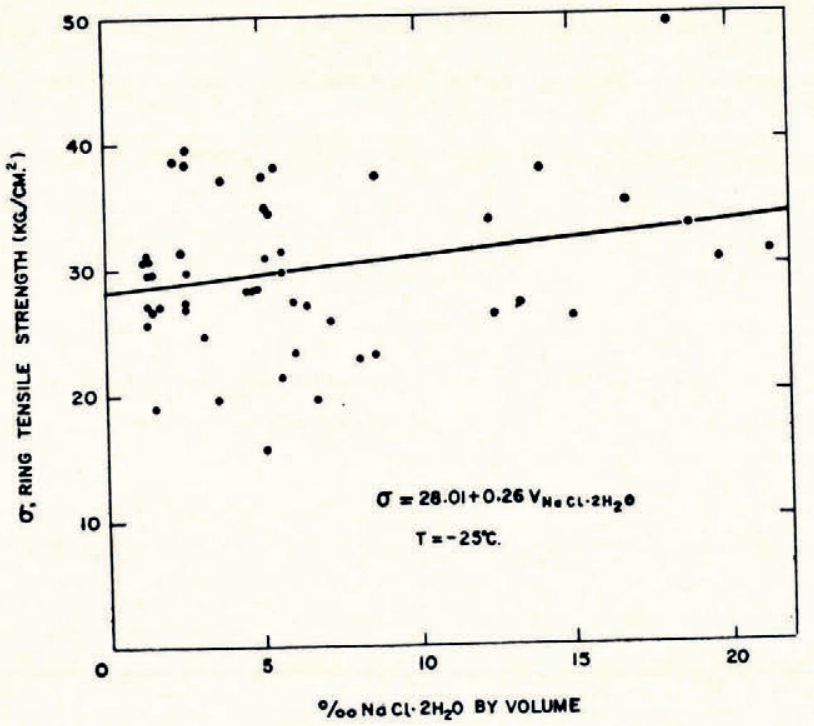

Fig. 7. Ring-tensile strength of $\mathrm{NaCl} \cdot{ }_{2} \mathrm{H}_{2} \mathrm{O}$ ice vs $\mathrm{V}\left(\mathrm{NaCl} \cdot{ }_{2} \mathrm{H}_{2} \mathrm{O}\right), \mathrm{T}=-25^{\circ} \mathrm{C}$.

changes in test temperature, indicating that the reduction of the strength of salt ice above the eutectic point can be considered, as suggested by Assur (1958), a unique function of brine volume independent of the individual temperature and salinity values. This shows that the strength of the ice-to-ice bonds between the brine pockets can be considered as temperature independent. This conclusion is not surprising, since the tensile strength of pure ice was also found to be essentially temperature independent.

Strength of $\mathrm{NaCl} \cdot{ }_{2} \mathrm{H}_{2} \mathrm{O}$ ice as a function of the relative volume of solid salt

Among the more interesting hypotheses in Assur's paper (1958) are: (I) that the presence of solid salt, in particular $\mathrm{NaCl} \cdot{ }_{2} \mathrm{H}_{2} \mathrm{O}$, reinforces the brine pockets, causing the strength of cold sea ice to become more than twice the strength of fresh-water ice; and (2) that the strength of this ice may be dependent on both the amount of solid salt in the ice and the ice temperature. The larger the amount of solid salt, the higher the strength. To test these hypotheses, a number of ring-tensile tests were performed on ice containing solid $\mathrm{NaCl} \cdot{ }_{2} \mathrm{H}_{2} \mathrm{O}$. The ringtensile strengths of these samples at $-25^{\circ},-30^{\circ}$ and $-35^{\circ} \mathrm{C}$. are plotted against the volume of the solid $\mathrm{NaCl} \cdot{ }_{2} \mathrm{H}_{2} \mathrm{O}$ in Figures 7 and 8 . The variation in the amount of solid salt in these 
samples is considerably greater than would ever be found in natural sea ice. No correlation was found between $V\left(\mathrm{NaCl} \cdot{ }_{2} \mathrm{H}_{2} \mathrm{O}\right)$ and the strength of the ice in the salinity range studied. The strength values also apparently are not temperature dependent.

Even if there is no correlation between $\sigma$ and $V\left(\mathrm{NaCl} \cdot{ }_{2} \mathrm{H}_{2} \mathrm{O}\right)$, the average strength of the $\mathrm{NaCl} \cdot{ }_{2} \mathrm{H}_{2} \mathrm{O}$ ice might still be considerably greater than the strength of fresh water ice. It is clear that this is not the case. The $V\left(\mathrm{NaCl} \cdot{ }_{2} \mathrm{H}_{2} \mathrm{O}\right)=0$ intercept for $-25^{\circ},-30^{\circ}$ and $-35^{\circ} \mathrm{C}$. samples combined is $28 \cdot 8 \pm 4 \cdot 17 \mathrm{~kg} . / \mathrm{cm} .^{2}$, which is comparable to the average value for the strength of fresh-water ice, $27 \cdot 5^{8} \pm 9 \cdot 18 \mathrm{~kg} . / \mathrm{cm} .^{2}$, obtained by the present author. It is concluded that, within the temperature and salinity range studied in this paper, the ring-tensile strength of $\mathrm{NaCl} \cdot{ }_{2} \mathrm{H}_{2} \mathrm{O}$ ice is:

(a) essentially independent of temperature and $\mathrm{V}\left(\mathrm{NaCl} \cdot{ }_{2} \mathrm{H}_{2} \mathrm{O}\right)$, and

(b) comparable to the strength of fresh water ice.

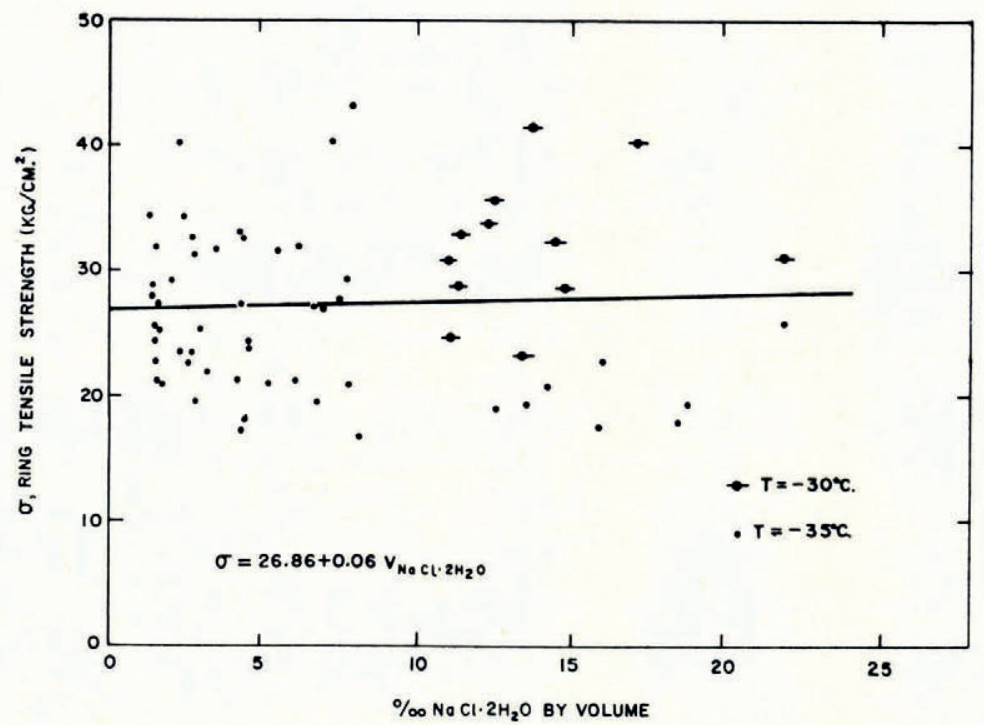

Fig. 8. Ring-tensile strength of $\mathrm{NaCl} \cdot{ }_{2} \mathrm{H}_{2} \mathrm{O}$ ice vs $\mathrm{V}\left(\mathrm{NaCl} \cdot{ }_{2} \mathrm{H}_{2} \mathrm{O}\right), \mathrm{T}=-30^{\circ} \mathrm{C}$. and $-35^{\circ} \mathrm{C}$.

These observations can be explained if we assume that, when the ice- $\mathrm{NaCl} \cdot{ }_{2} \mathrm{H}_{2} \mathrm{O}$ eutectic mixture crystallizes in a brine pocket, the former brine pocket has either the same or a greater strength than the ice matrix. The failure, therefore, presumably occurs in the ice matrix, causing the ring-tensile strength of the aggregate to be similar to the ring-tensile strength of fresh-water ice. It is, of course, probable that large volumes of $\mathrm{NaCl} \cdot{ }_{2} \mathrm{H}_{2} \mathrm{O}$ in the ice will cause a systematic shift in the strength of the aggregate. Otherwise, it would be necessary to suppose that the properties of pure ice and pure $\mathrm{NaCl} \cdot{ }_{2} \mathrm{H}_{2} \mathrm{O}$ are similar. Although no data are available on the strength characteristics of $\mathrm{NaCl} \cdot{ }_{2} \mathrm{H}_{2} \mathrm{O}$, such a coincidence is considered highly improbable.

\section{Effect of thermal history on salt ice strength}

A number of alternate hypotheses have been advanced to explain apparently anomalous strength variations between sea ice from different test sites and with different thermal histories. The first of these requires a change in the bulk chemistry of the sea ice and is based on the field observation (Zubov, I945) that, as sea ice ages, the chloride/sulfate ratio is decreased by differential drainage of NaCl-rich brine from the ice. The crystallization temperature of 
$\mathrm{Na}_{2} \mathrm{SO}_{4} \cdot \mathrm{IOH}_{2} \mathrm{O}$ is $-8 \cdot 7^{\circ} \mathrm{C}$. from a sea-water brine and only $-\mathrm{I} \cdot 2^{\circ} \mathrm{C}$. from a $\mathrm{Na}_{2} \mathrm{SO}_{4}-$ $\mathrm{H}_{2} \mathrm{O}$ solution. Assur (1958) has noted that this change would be reflected in the volumes of brine and solid salt in the ice and might be at least partly responsible for the differences between the strength characteristics of young sea ice and perennial pack ice. This hypothesis will be referred to as the "compositional effect".

Other hypothetical explanations for strength variations are concerned only with the physical state of the ice-solid salt-brine system and do not require changes in the bulk chemistry. For example, when a sample of ice is heated, there might be a measurable lag between the time it arrives at the higher temperature and the time that the equilibrium amount of icebrine-solid salt is achieved. The sample would, therefore, retain its strength of the lower temperature for several hours after reaching the higher temperature, and then slowly weaken. This possible effect will be referred to as "phase hysteresis" since it is a kinetic phenomenon associated with the metastable persistence of an unstable phase.

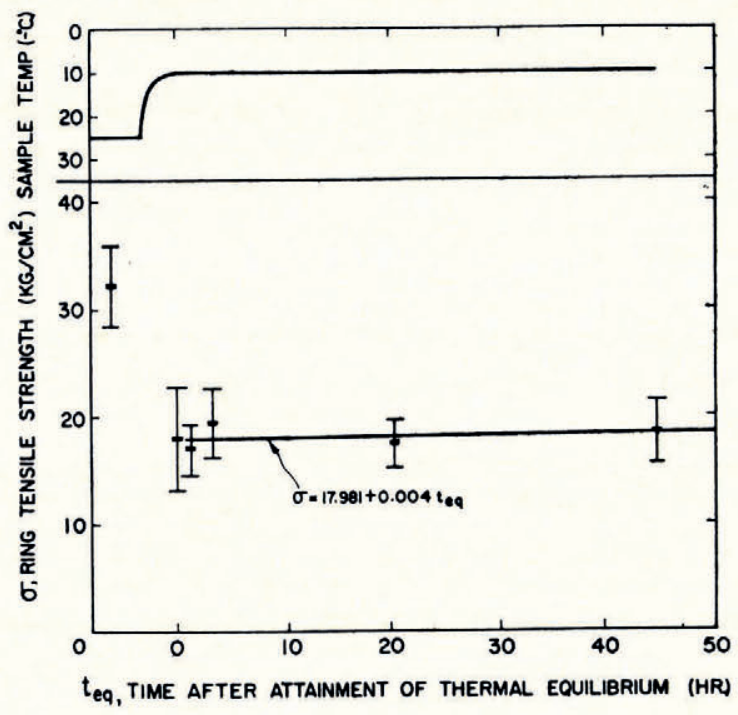

Fig. 9. Study of phase hysteresis in $\mathrm{NaCl}$ ice, $T_{t}=-10^{\circ} \mathrm{C}$.

A third hypothesis is that the geometry of the brine pockets and the distribution of solid salt in the ice are a function of the specific thermal path by which the ice sample approached the test temperature. If so, ice tested after being subjected to a warming cycle might not give the same strength values as ice tested after being subjected to a cooling cycle. This effect will be referred to as "geometric hysteresis".

The other important factors which may influence sea-ice strength are probably related to the specific thermal history of the ice sheet during its nucleation and growth. Among these might be such factors as initial grain orientation, grain size, the geometry of the sub-plates that compose the single crystals of sea ice, and the initial shapes of the brine pockets. All of the ice used in the studies reported in this paper was grown under identical thermal conditions, therefore it is assumed that these factors, if important in controlling the strength of the ice, are constant for the present freezing runs.

Although the "compositional effect" could be studied in the laboratory, it would necessitate aging the ice for long periods under carefully controlled conditions. Therefore, experimentation was concentrated on studies of "phase" and "geometric hysteresis". 
Phase hysteresis. To test for the presence of $\mathrm{NaCl} \cdot{ }_{2} \mathrm{H}_{2} \mathrm{O}$ phase hysteresis, 6o ring tensile samples from Run IV were stored at $-25^{\circ} \mathrm{C}$. (below the eutectic point of the $\mathrm{NaCl}-\mathrm{H}_{2} \mathrm{O}$ system). First ten of these samples were tested at $-25^{\circ} \mathrm{C}$. Then a dummy sample with a thermocouple frozen into it was warmed from $-25^{\circ}$ to $-10^{\circ} \mathrm{C}$. and the change in temperature with time was measured. It was found that the ice sample reached thermal equilibrium at $-\mathrm{IO}^{\circ} \mathrm{C}$. in $3 \mathrm{hr}$. The remaining $5^{\circ}$ samples were then moved from $-25^{\circ}$ to $-10^{\circ} \mathrm{C}$. and allowed to reach thermal equilibrium. Ring-tensile tests were then performed on the first group of ten samples. Similar tests were made at about 1, 3, 24, and $48 \mathrm{hr}$. intervals after the time of thermal equilibrium $\left(t_{e q}=0\right)$. These results are shown in Fig. 9. The correlation coefficient and $t$-number for the fitted curve are $0 \cdot 090$ and $0 \cdot{ }_{1} 66$ respectively. It is obvious that, in the samples studied, the achievement of thermal equilibrium is accompanied by the achievement of tensile strength equilibrium and that there is no evidence of a phase hysteresis.

A proof of an absence of phase hysteresis in $\mathrm{NaCl} \cdot{ }_{2} \mathrm{H}_{2} \mathrm{O}$ ice does not, of course, rule out

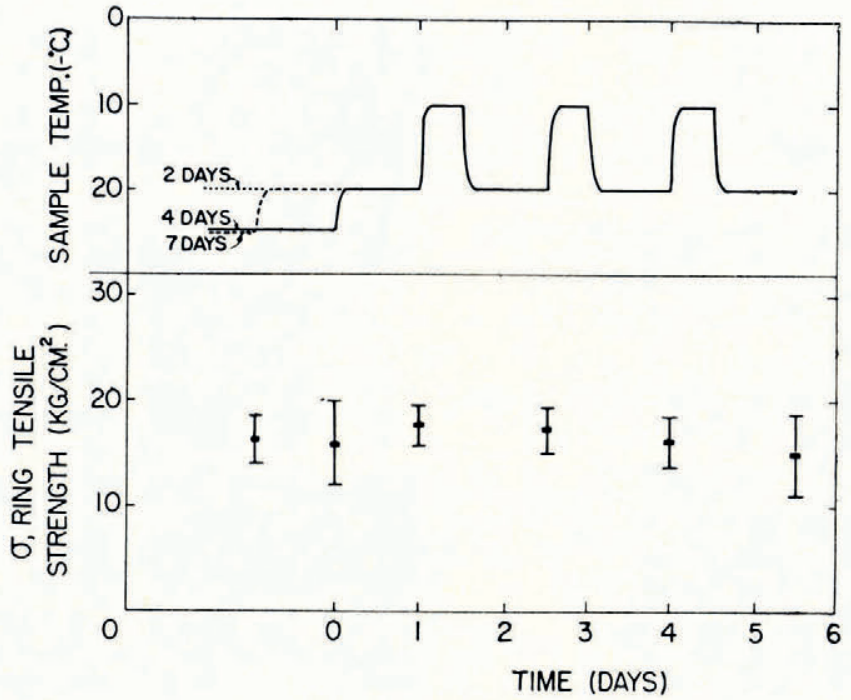

Fig. IO. Study of geometric hysteresis in $\mathrm{NaCl}$ ice, Run V, $T_{t}=-20^{\circ} \mathrm{C}$., cycled to $-10^{\circ} \mathrm{C}$.

the possibility of phase hysteresis in $\mathrm{Na}_{2} \mathrm{SO}_{4} \cdot 10 \mathrm{H}_{2} \mathrm{O}$ ice. However, even if sea-water were initially frozen in a closed system, the maximum amount of $\mathrm{Na}_{2} \mathrm{SO}_{4} \cdot \mathrm{IOH}_{2} \mathrm{O}$ present at $-34^{\circ} \mathrm{C}$. would be $8.88 \mathrm{~g}$. for $922 \mathrm{~g}$. of ice or $9.63 \%$ by weight (Assur, 1958). If differential brine drainage were to proceed at maximum efficiency and remove all other ions, this value is still well below the solubility of $\mathrm{Na}_{2} \mathrm{SO}_{4} \cdot{ }_{1} \mathrm{H}_{2} \mathrm{O}$ in water at its eutectic point $(38 \%$ by weight).

Geometric hysteresis. To study geometric hysteresis, 6o ring-tensile samples from Run IV were subjected to different thermal histories. One group of 10 samples was tested at $-20^{\circ} \mathrm{C}$. immediately after being removed from the freezing tank. Since the air temperature in the freezing room was regulated at $-20^{\circ} \mathrm{C}$., these samples had never been below the eutectic temperature. Two other groups of samples were stored at $-25^{\circ} \mathrm{C}$. for varying periods of time then moved to $-20^{\circ} \mathrm{C}$. and tested after being allowed to reach thermal equilibrium. The remaining samples, after being at $-25^{\circ} \mathrm{C}$., were cycled between $-10^{\circ}$ and $-20^{\circ} \mathrm{C}$. until testing was completed. These data are presented in Figure io. As can be seen, there is no correlation between the ring tensile strength at $-20^{\circ} \mathrm{C}$, and the specific thermal path that the 
samples followed before reaching the test temperature. There is, therefore, no measurable geometric hysteresis in salt ice, and consequently it should be permissible to group tests on natural sea ice, regardless of their thermal history, provided, of course, that the different test groups have similar bulk chemistries.

Four series of tests were made to study the effects of thermal cycles on ice tested at temperatures below the eutectic point. Samples from Runs II and III were stored and tested at $-25^{\circ} \mathrm{C}$. and cycled to $-10^{\circ} \mathrm{C}$. Samples from Run VI were stored and tested at $-30^{\circ} \mathrm{C}$. and cycled to both $-20^{\circ}$ and $-10^{\circ} \mathrm{C}$. In all these samples, there was no doubt that $\mathrm{NaCl} \cdot 2 \mathrm{H}_{2} \mathrm{O}$ had crystallized prior to testing, since this crystallization is accompanied by a pronounced sample color change from grey to chalky white. A typical test series is shown in Figure I I. It is concluded that:

(a) The strength of the initial group of uncycled samples is significantly higher than that of the cycled samples.

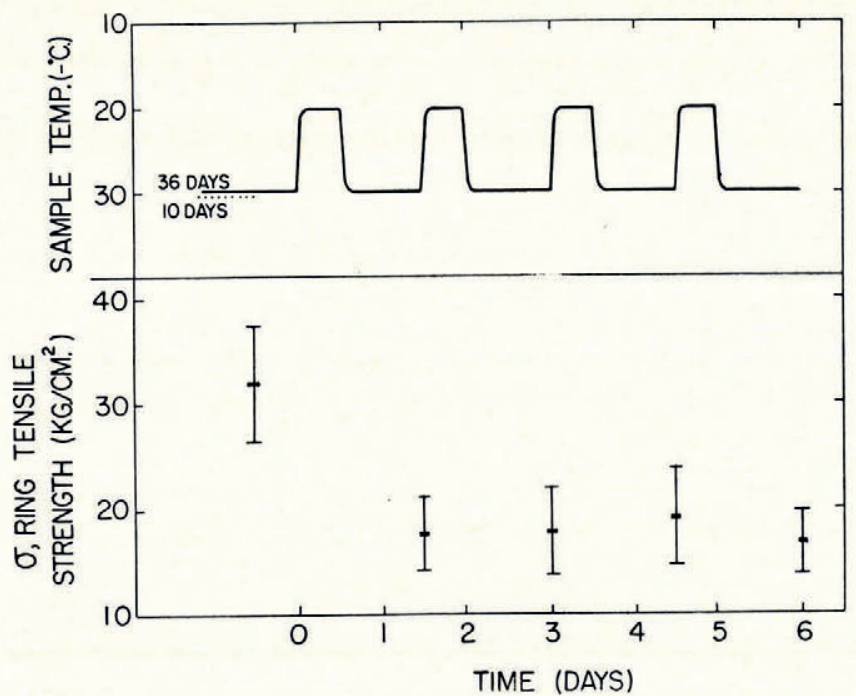

Fig. II. Study of geometric hysteresis in $\mathrm{NaCl} \cdot{ }_{2} \mathrm{H}_{2} \mathrm{O}$ ice, Run VI, $\mathrm{T}_{t}=-30^{\circ} \mathrm{C}$., cycled to $-20^{\circ} \mathrm{C}$.

(b) This decrease in strength usually occurs after the first cycle and is not affected by further cycles.

When first noted, it was believed that this strength decrease resulted from brine drainage at the higher temperatures. However, checks of the sealed polyethylene bags that contained the samples during the cycling process revealed no evidence of brine drainage. This observation is supported by the lack of change in the average salinities of the groups of samples as a function of the number of cycles to a higher temperature (Fig. 12). When the second group of samples was pulsed, visual examination revealed that there had been an appreciable redistribution of the brine in the sample during the high temperature portion of the cycle. This change is not evident when examining the samples at temperatures above the eutectic temperature. However, at sub-eutectic temperatures, the redistribution of brine can be seen because of the chalky color of the $\mathrm{NaCl} \cdot 2 \mathrm{H}_{2} \mathrm{O}$. No quantitative measurements have been made of this redistribution, but most of the brine apparently shifted to the lower portion of the sample.

In ring-tensile tests, failure is forced on a predetermined small volume. If the brine in this volume is drained away during a heating cycle, then when the sample is returned to the 
sub-eutectic temperature, the brine pockets will be filled with air instead of the eutectic mixture of $\mathrm{NaCl} \cdot{ }_{2} \mathrm{H}_{2} \mathrm{O}$ and ice. The ice should then have a strength corresponding to a temperature higher than the eutectic point.

It has been shown that the ring-tensile strength of salt ice $(\sigma)$ is approximately a function of $\sigma_{\mathrm{o}}\left(\mathrm{I}-\nu^{\frac{1}{2}}\right)$ and presumably also of $\sigma_{\mathrm{o}}\left(\mathrm{I}-V_{a}^{\frac{1}{2}}\right)$, where $V_{a}$ is the volume of air in the ice. Therefore

$$
\frac{d \sigma}{d \nu}=-\frac{\sigma_{o}}{2 \nu^{\frac{1}{2}}}
$$

and the strength decrease $\Delta \sigma_{b}$ produced by the volume of brine present in the ice during the high temperature portion of the thermal cycle $\left(\nu_{\max }\right)$ is obtained as

$$
\Delta \sigma_{b}=\int_{\sigma_{0}}^{\sigma} d \sigma=\int_{0}^{\nu_{\max }}-\frac{\sigma_{\mathrm{o}}}{2 \nu^{\frac{1}{2}}} d \nu=-\sigma_{\mathrm{o}} \nu_{\max }^{\mathrm{t}} .
$$

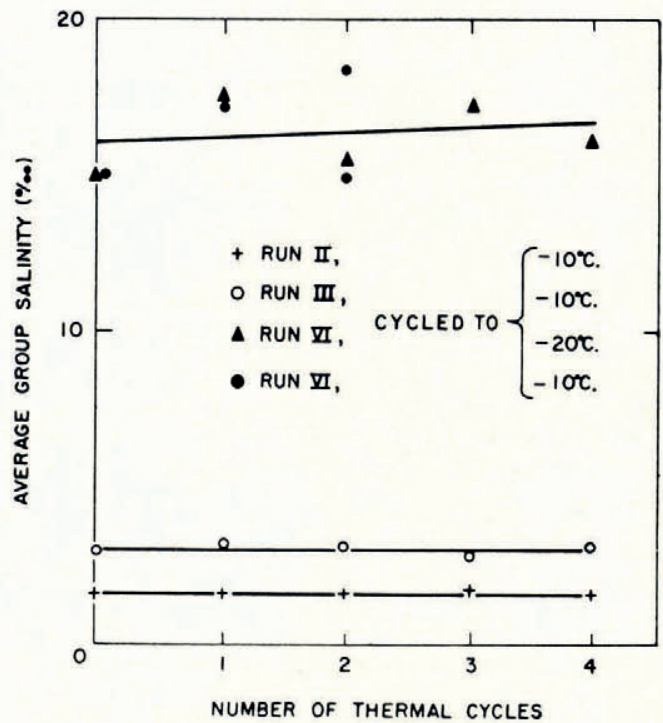

Fig. 12. Average test group salinity vs number of cycles to a higher temperature

If it is assumed that the loss in brine volume $(\Delta \nu)$ and the corresponding increase in the air content of the salt ice, as the result of thermal cycling, are proportional to the volume of brine present in the ice at the high temperature portion of the thermal cycle $\left(v_{\max }\right)$, then

and

$$
\begin{gathered}
\Delta \nu=\Delta V_{a}=c \nu_{\max } \\
\Delta \sigma \propto \nu_{\max }^{k} .
\end{gathered}
$$

where $\Delta \sigma$ is the strength decrease due to cycling.

If these assumptions are valid, a plot of $\log \Delta \sigma v s \log v_{\max }$ should be a straight line with a slope of 0.5 . The slope of the line in Figure $\mathrm{I}_{3}$ is 0.43 and is not significantly different from 0.5 at the 0.95 probability level.

This phenomenon, which will be called the "brine redistribution effect", has obvious implications for planning optimum testing procedures for natural sea ice. The best procedure, of course, is to test the sea ice immediately after removal from the ice sheet at the in situ temperature. If this is not possible, samples of $\mathrm{NaCl}$ ice should be stored at temperatures 
below the eutectic point, and samples of sea ice below the $\mathrm{NaCl} \cdot{ }_{2} \mathrm{H}_{2} \mathrm{O}$ crystallization temperature $\left(-2 \dot{2} \cdot 9^{\circ} \mathrm{C}\right.$. $)$. If storage is necessary and low temperatures are unavailable, brine redistribution can possibly be minimized by rotating the samples every few hours and by not drilling the co-axial hole until shortly before the ring-tensile tests are performed.

It is also of interest to note that the brine redistribution effect, while clearly evident in ice tested at sub-eutectic temperatures, is not apparent in ice tested at temperatures above the eutectic point (see Fig. I0). This appears to indicate that, while there is a large strength difference between a volume filled with air and one filled with the $\mathrm{NaCl} \cdot{ }_{2} \mathrm{H}_{2} \mathrm{O}$-ice eutectic mixture, there is no appreciable strength difference between a volume filled with air and one filled with brine.

Effect of short-term cooling on the strength of fresh-water and $\mathrm{NaCl} \cdot{ }_{2} \mathrm{H}_{2} \mathrm{O}$ ice. As was noted earlier, there is a consistent difference between the ring-tensile strengths measured from the two

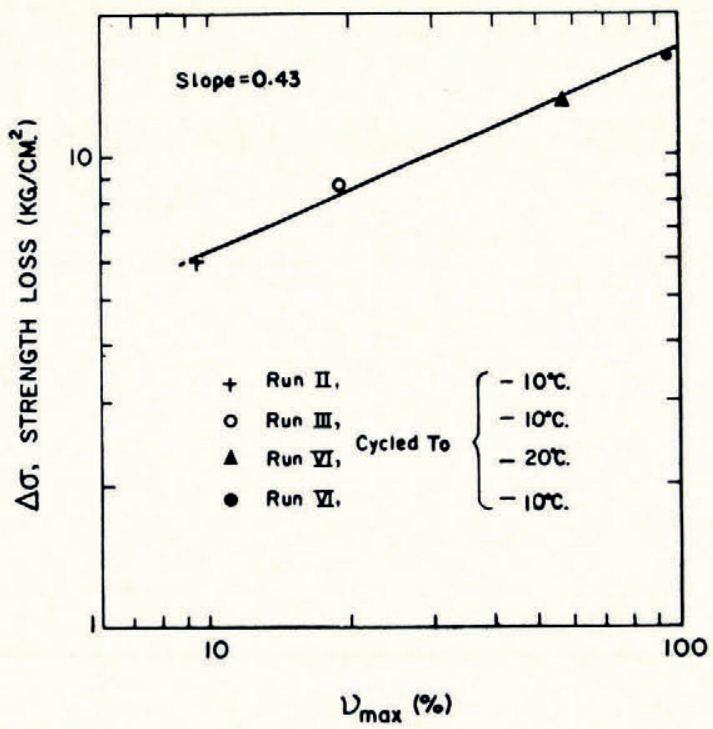

Fig. 13. $\log (\Delta \sigma)$, the strength loss due to cycling, vs $\log v_{\max }$ the volume of brine present in the ice during the high temperature portion of the thermal cycle

fresh-water ice freezing runs. Since the ice from both runs is apparently quite similar in grain size and crystal orientation, it is reasonable to hypothesize that these differences are the result of changes in treatment.* Examination of the data shows that there are two main types of testing procedures for the fresh ice. The samples in the first group were stored for over two months at $-25^{\circ} \mathrm{C}$. before being tested, while samples in the second group were not subjected to prolonged storage, but quickly brought from the growth tank to the test temperature and tested after one day. To compare these strength values, it is necessary to reduce them to a common temperature $\left(-10^{\circ} \mathrm{C}\right.$.) by using a relation suggested by Assur (personal communication, r960).

$$
\sigma_{a}=\frac{\mathrm{1} 60}{\mathrm{I} 50-T_{t}} \sigma
$$

where $T_{t}$ is the test temperature in ${ }^{\circ} \mathrm{C}$., $\sigma$ is the observed ring-tensile strength at temperature

* This possibility, that the strength differences between Runs I and VII were the result of changes in treatment instead of changes in the freezing process, was suggested to the author by Dr. A. Assur. 
$\tau_{t}$, and $\sigma_{a}$ is the adjusted ring-tensile strength. This correction is rather small with a temperature coefficient of $0 \cdot 00667$ and is in agreement with both the results of the present study and the work of Butkovich (1954). The standard deviations are adjusted, using the same ratio. The average strength and the standard error of the average $\bar{S}=s / n^{\frac{1}{2}}$ where $s$ is the standard deviation and $n$ is the number of samples, are $29 \cdot 40 \pm[\mathrm{r} \cdot 69] \mathrm{kg} . / \mathrm{cm} .{ }^{2}$ for the groups subject to prolonged storage* and $23 \cdot 63 \pm[\mathrm{I} \cdot 24] \mathrm{kg} . / \mathrm{cm} .^{2}$ for the unstored groups. Both of these values are based upon the averages of the individual test groups. If the average and standard deviation are computed from the individual test results, we obtain $29 \cdot 5^{8} \pm 8 \cdot 47$ $\mathrm{kg}$. $/ \mathrm{cm} .^{2}$ for group I and $23 \cdot 60 \pm 5 \cdot 75 \mathrm{~kg} . / \mathrm{cm} .^{2}$ for group 2. The standard errors are $[\mathrm{I} \cdot \mathrm{I} 75]$ and $[0.6466]$ respectively. In both cases, the standard error based upon group averages is higher than that based upon the individual values indicating that there are more systematic effects involved than just the separation into the two groups.

The significance of the difference can be tested by computing the statistic

$$
t=\left|\sigma_{\mathrm{I}}-\sigma_{2}\right| /\left\{\bar{S}_{\mathrm{I}}^{2}+\bar{S}_{2}^{2}\right\}^{\frac{1}{2}}
$$

which in this case is equal to $4 \cdot 46$. Since there are 129 degrees of freedom, the critical $t$ number for a significant difference at the 99 per cent level is $2 \cdot 62$. Therefore, we can conclude that there is a difference between the two groups of data. The cause of this difference appears to be the change in the testing procedure. However, since the samples in Group I are from Run I, and the samples in Group 2 are from Run VII, it is also possible that the strength differences are the result of some basic change in the strength of the ice from the different runs. Unfortunately, different sample groups from the same fresh-ice freezing run were not subjected to different aging histories.

The correlation between short-term cooling and strength decrease can be tested by studying the strength variation of $\mathrm{NaCl} \cdot{ }_{2} \mathrm{H}_{2} \mathrm{O}$ ice. As shown earlier, the strength of $\mathrm{NaCl} \cdot{ }_{2} \mathrm{H}_{2} \mathrm{O}$ ice is independent of the amount of $\mathrm{NaCl} \cdot 2 \mathrm{H}_{2} \mathrm{O}$ present in the ice, and is comparable to the strength of fresh-water ice. This was interpreted as indicating that the strength of $\mathrm{NaCl} \cdot{ }_{2} \mathrm{H}_{2} \mathrm{O}$ ice is controlled by the strength of the ice matrix. Therefore, if the strength of fresh-water ice is affected by short-term cooling, the strength of $\mathrm{NaCl} \cdot{ }_{2} \mathrm{H}_{2} \mathrm{O}$ ice should also be affected. To test this, strength values of $\mathrm{NaCl} \cdot 2 \mathrm{H}_{2} \mathrm{O}$ ice were corrected to $-10^{\circ} \mathrm{C}$., using equation (10). This correction accounts only for the change in strength of the fresh ice component and ignores the presence of the brine pockets. These tests can also be separated into two groups. The first group was subjected to rapid cooling by $5^{\circ}$ to $10^{\circ} \mathrm{C}$. after storage, while the samples in group 2 were either tested at the storage temperature or after being warmed $5^{\circ}$. The averages and standard errors of the group averages are $21 \cdot 99 \pm[\mathrm{r} \cdot 22]$ and $27 \cdot 37 \pm[\mathrm{r} \cdot 23] \mathrm{kg} \cdot / \mathrm{cm}{ }^{2}$ If the weighted averages and standard errors are computed from the whole population instead of from the group averages, values of $22 \cdot 30 \pm[0 \cdot 75]$ and $26 \cdot 49 \pm[0 \cdot 72] \mathrm{kg} . / \mathrm{cm}{ }^{2}$ are obtained. Similarly to those for fresh-water ice, the standard errors based on the group means are larger than those based on the individual test values, indicating that the group averages probably still contain hidden effects. The computed $t$-number is $4^{\circ} .03$ as compared with the required $t$-number of $2 \cdot 63$ for a difference at the 99 per cent. level of significance. Therefore, it can be concluded that there is a statistically significant difference between the two sample groups, both in $\mathrm{NaCl} \cdot{ }_{2} \mathrm{H}_{2} \mathrm{O}$ ice and fresh-water ice.

This strength drop is probably caused by thermal shock, which produces small defects in the sample that do not heal in a day. Also, in $\mathrm{NaCl} \cdot{ }_{2} \mathrm{H}_{2} \mathrm{O}$ ice, when samples are moved from the temperature of the freezing tank to a sub-eutectic test temperature, the new eutectic mixture occupies 7.2 per cent more volume than the original brine pocket at the eutectic temperature. This sudden volume change will probably produce cracks in the pure-ice matrix and cause a strength decrease. In addition, once the eutectic mixture has formed, the larger thermal contraction of the fresh-ice component, as compared to the $\mathrm{NaCl} \cdot{ }_{2} \mathrm{H}_{2} \mathrm{O}$ inclusions,

* When the standard error $\bar{S}$ is given after an average, it is inclosed in brackets. 
would produce strains and cracks in the ice matrix. If these factors are predominant, the $\mathrm{NaCl} \cdot 2 \mathrm{H}_{2} \mathrm{O}$ ice should exhibit a more pronounced strength decrease as a result of short term cooling than fresh ice. The sudden cooling reduces the strength of the fresh-water ice by $5 \cdot 98 \pm[\mathrm{I} \cdot 34] \mathrm{kg} . / \mathrm{cm}^{2}$ and the $\mathrm{NaCl} \cdot{ }_{2} \mathrm{H}_{2} \mathrm{O}$ ice by $4 \cdot 19 \pm[\mathrm{I} \cdot 04] \mathrm{kg} \cdot / \mathrm{cm} .{ }^{2}$ or $20 \cdot 2 \pm$ $[4 \cdot 53]$ and $15 \cdot 8 \pm[3 \cdot 93]$ per cent in relative terms. The computed $t$-number for the significance of the difference between the fresh-water and salt ice values is 0.73 and the required $t$-number is 3.03 . Therefore, there is no significant difference between fresh and $\mathrm{NaCl}$. $2 \mathrm{H}_{2} \mathrm{O}$ ice in strength reduction produced by short-term cooling, indicating that the strength reduction is apparently the result of changes in the strength characteristics of the pure-ice part of the sample.

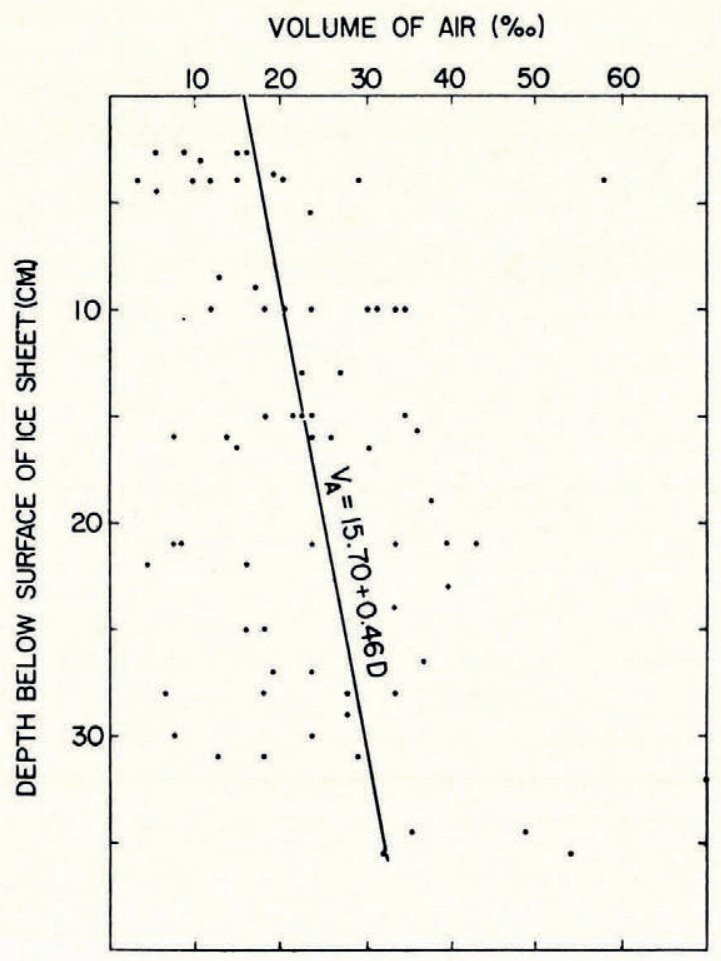

Fig. 14. Volume of air in the ice vs depth in the ice sheet, Run VI

We can assume that the ring-tensile strength of fresh-water ice is $29 \cdot 5^{8} \pm 8 \cdot 34 \mathrm{~kg} . / \mathrm{cm} .^{2}$ $\left(5^{2}\right.$ tests) at $-10^{\circ} \mathrm{C}$., while the strength of $\mathrm{NaCl} \cdot{ }_{2} \mathrm{H}_{2} \mathrm{O}$ ice is $26 \cdot 49 \pm 5 \cdot 67 \mathrm{~kg} . / \mathrm{cm} .{ }^{2}(62$ tests) if the strength of its ice matrix is corrected to $-10^{\circ} \mathrm{C}$. The $t$-number indicates that this difference is significant at the 95 per cent level, but not at the 99 per cent level. Although a difference in strength is not proved, the statement that salt ice below the eutectic point has the same strength as fresh-water ice should be doubted. Since the average test temperature for the samples used in computing the average strength of $\mathrm{NaCl} \cdot{ }_{2} \mathrm{H}_{2} \mathrm{O}$ ice is $-25 \cdot 8^{\circ} \mathrm{C}$., the strength value, when recalculated to this temperature, is $29 \cdot 1 \mathrm{I} \pm 6 \cdot 23 \mathrm{~kg} . / \mathrm{cm} .{ }^{2}$.

Usually, when natural fresh-water ice is tested, there is an appreciable difference between the air temperature and the in situ ice temperature. The samples are removed from the ice sheet, allowed to come to equilibrium with the air temperature, and then immediately tested. This procedure will cause thermal shock in the test samples and probably partly accounts for 
the apparent discrepancy between the strength of natural fresh-water ice and laboratcry and glacier ice.

\section{Effect of the volume of inclosed air on the strength of salt ice}

Density determinations were made by a procedure similar to that used by all recent field investigators. A sample of ice is cut out and its dimensions and weight determined. Unfortunately, an analysis of the error involved shows that even if the diameter of the ice specimen is exactly that of the corer, an error of $\pm 0.5 \mathrm{~mm}$. in measuring the length of the sample would produce an error of approximately $\mathrm{I} \cdot 5 \mathrm{per}$ cent. Also the external diameter of the core may deviate appreciably from the internal diameter of the corer due to grooving and gouging

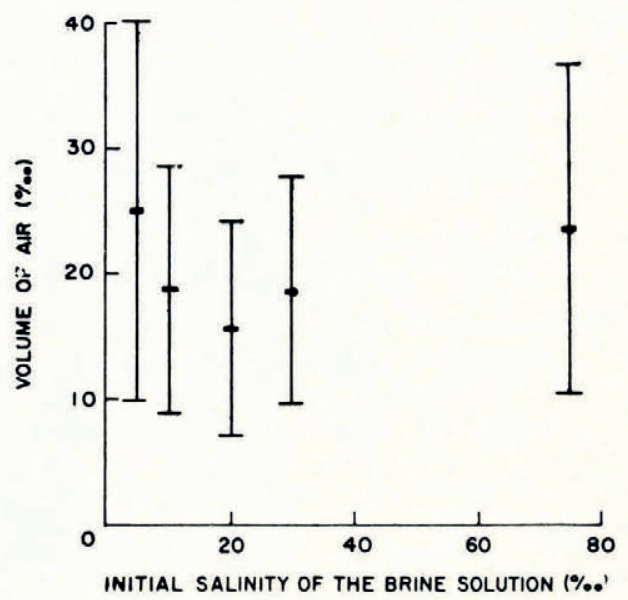

Fig. 15. Average volume of air in the ice of a given run vs initial salinity of the freezing solution

during coring and the formation of slush coatings after coring. These combined effects could easily produce an error greater than 2 per cent in any density measurements.

Unfortunately, such an error is of the same order of magnitude as the density decrease produced by the volume of air included in the ice. Figure 14 shows the volume of air in the ice plotted against the depth of the sample below the surface of the ice sheet for Run VI. The other freezing runs give similaı results. In general, there is a slight increase in the volume of air in the ice with increasing depth. Such a result is quite reasonable, since the volume of brine in the in situ ice sample increases toward the lower portion of the sample. This higher brine volume facilitates brine drainage from the lower part of the ice core immediately after it is removed from the ice sheet, therefore, causing a higher volume of included air. There is a high scatter in the density values for a given ice. Much of this is undoubtedly the result of the error in the density determination. Figure 15 shows the average volume of air included in the ice of a given run plotted against the composition of the initial freezing solution. There does not appear to be a correlation. The effect of the total void volume-volume of air plus the volume of brine - on the ring-tensile strength of the salt ice was also studied. The conclusions are similar to those reached from considering only the volume of brine.

It is suggested that a more accurate immersion method should be used for density measurements in the future. Such a study could perhaps resolve the question of the differences, if any, between the strength characteristics of ice containing brine pockets and air bubbles. As mentioned earlier, some of the data collected in this study appear to indicate that there is no major difference. This evidence is far from conclusive, however. 


\section{Conclusions}

$\mathrm{NaCl}$ ice

The main conclusions reached in the present study may be summarized briefly, as follows:

I. The ring-tensile strength of fresh-water ice is essentially temperature independent in the temperature range $-10^{\circ}$ to $-30^{\circ} \mathrm{C}$. and shows a slight decrease at $-5^{\circ} \mathrm{C}$. The individual test groups show a large scatter. For the present, $29 \cdot 6 \pm 8 \cdot 5 \mathrm{~kg} . / \mathrm{cm} .^{2}$ will be considered as the average strength of pure ice with no visible air bubbles or cracks at $-10^{\circ} \mathrm{C}$. This value is comparable to recent ring-tensile results from glacier ice (Butkovich, 1959[a]).

2. The ring tensile strength of ice containing crystals of $\mathrm{NaCl} \cdot{ }_{2} \mathrm{H}_{2} \mathrm{O}$ is essentially independent of both the temperature of the sample and the volume of $\mathrm{NaCl} \cdot{ }_{2} \mathrm{H}_{2} \mathrm{O}$ present in the ice. This indicates that the brine pockets are reinforced and the failure occurs in the ice matrix. If the strength of the ice matrix is corrected to $-\mathrm{IO}^{\circ} \mathrm{C}$., the strength of $\mathrm{NaCl} \cdot 2 \mathrm{H}_{2} \mathrm{O}$ ice is $26 \cdot 5 \pm 5 \cdot 7 \mathrm{~kg} . / \mathrm{cm} .{ }^{2}$. This corresponds to a value of $29 \cdot \mathrm{II} \pm 6 \cdot 23 \mathrm{~kg}$. $/ \mathrm{cm} .^{2}$ at the average test temperature of $-25 \cdot 8^{\circ} \mathrm{C}$.

3. A $t$-test for the significance of the difference of means indicates that there is a difference between the strength of fresh-water ice and $\mathrm{NaCl} \cdot{ }_{2} \mathrm{H}_{2} \mathrm{O}$ ice at the 95 per cent level of significance but not at the 99 per cent level. Therefore, the statement that the strengths of fresh-water and $\mathrm{NaCl} \cdot{ }_{2} \mathrm{H}_{2} \mathrm{O}$ ice are identical should be doubted.

4. The strength of $\mathrm{NaCl}$ ice above the eutectic point decreases with an increase in the volume of brine in the ice and can be considered a unique function of the brine volume, independent of the individual temperature and salinity values. The presently available data do not permit a choice between the functions

$$
\sigma=f_{l}(\nu), \sigma=f_{l}\left(\nu^{\frac{1}{2}}\right) \text { or } \sigma=f_{l}\left(\nu^{\frac{2}{3}}\right) .
$$

When the average ring-tensile strengths of the different test groups are plotted against $\nu_{a v}^{\ddagger}$ for each group, the data can be adequately represented by the equation $\sigma_{a v}=24 \cdot 7 \mathrm{I}$ $-5 \cdot 15 \nu_{a v}^{b}$ (Fig. I6).

The intercepts $\left(\sigma_{\mathrm{o}}\right)$ of the $\sigma=f_{l}\left(\nu^{k}\right)$ lines with the $\sigma$ axis indicate the extrapolated strength of salt ice at the zero-brine condition. Following Assur (1958), we define $\sigma_{o}$ as the basic strength of salt ice as determined by ring-tensile test. Since the test data do not allow a choice between the different powers of $\nu$, possible values of $\sigma_{0}$, determined by linear extrapolation, vary from 19.4 to $24.7 \mathrm{~kg} . / \mathrm{cm}^{2}$ (Table II). To compare with Assur (1958), we

Table II. Comparison of Values for the Basic Strength of Salt Ice $\left(\sigma_{0}\right)$ and the Zero Strength Condition $\left(\nu_{0}\right)$ as Determined from Plots of $\sigma$ Against Different Brine Volume Parameters

\begin{tabular}{|c|c|c|c|c|c|}
\hline $\begin{array}{c}\text { Test } \\
\text { temperature }\end{array}$ & $\begin{array}{c}\text { Data } \\
\text { grouping }\end{array}$ & $\begin{array}{c}\text { Power }(k) \\
\text { of } \nu\end{array}$ & $\begin{array}{c}\text { Basic strength } \\
\text { of salt ice } \sigma_{\circ} \\
\mathrm{kg} \cdot / \mathrm{cm} .^{2}\end{array}$ & $\begin{array}{c}\text { Zero strength } \\
\text { condition } v_{\mathrm{O}} \\
\% \text { oo }\end{array}$ & Reference \\
\hline All $T$ & $\begin{array}{l}\text { Average } \\
\text { values }\end{array}$ & I & 19.39 & 194 & This paper \\
\hline $\begin{array}{l}\text { All } T \\
\text { All } T\end{array}$ & , & $\frac{1}{2}$ & $\begin{array}{l}24 \cdot 71 \\
21 \cdot 96\end{array}$ & $\begin{array}{l}231 \\
212\end{array}$ & , \\
\hline$T_{\text {All }} T-8 \cdot 2$ & ", & $\begin{array}{l}\frac{3}{3} \\
\frac{1}{2}\end{array}$ & $\begin{array}{l}14 \cdot 20 \\
24 \cdot 80\end{array}$ & $\begin{array}{l}212 \\
393 \\
331\end{array}$ & $\begin{array}{l}\text { Assur ('1958) } \\
\text { Langleben (1959) }\end{array}$ \\
\hline
\end{tabular}

will, for the remainder of this paper, use $\sigma_{0}=24 \cdot 7 \pm \mathrm{I} \cdot 6 \mathrm{~kg} . / \mathrm{cm} .^{2}$ as determined from the plot of $\sigma_{a v} v s \nu_{a v}^{\ddagger}$ (Fig. I6).

5. A $t$-test for the significance of the difference of means indicates that there is a difference at the 0.99 level of significance between the average strength of fresh-water ice and $\sigma_{0}$, the basic strength of salt ice as determined from Figure 16.

This indicates that the ratio of the stress concentration in salt ice to that in fresh water ice is $\mathrm{I} \cdot 20$. It should, of course, be noted that some uncertainty is introduced into the calculation of this ratio by the failure of the strength tests to indicate a unique value for the exponent 
of $\nu$. In any case, it may be concluded that the ratio is slightly greater than $\mathrm{I}$ in the range $\mathrm{I} \cdot \mathrm{I}$ to $\mathrm{I} \cdot 5$. It definitely is not 3 , as initially suggested by Anderson and Weeks (1958). This is not meant to imply that the stress concentration factor for a small, isolated circular brine pocket would not be 3 , but only that whatever stress concentration is introduced in sea ice by the presence of brine pockets is also largely present in the fresh-water ice studied in this paper.

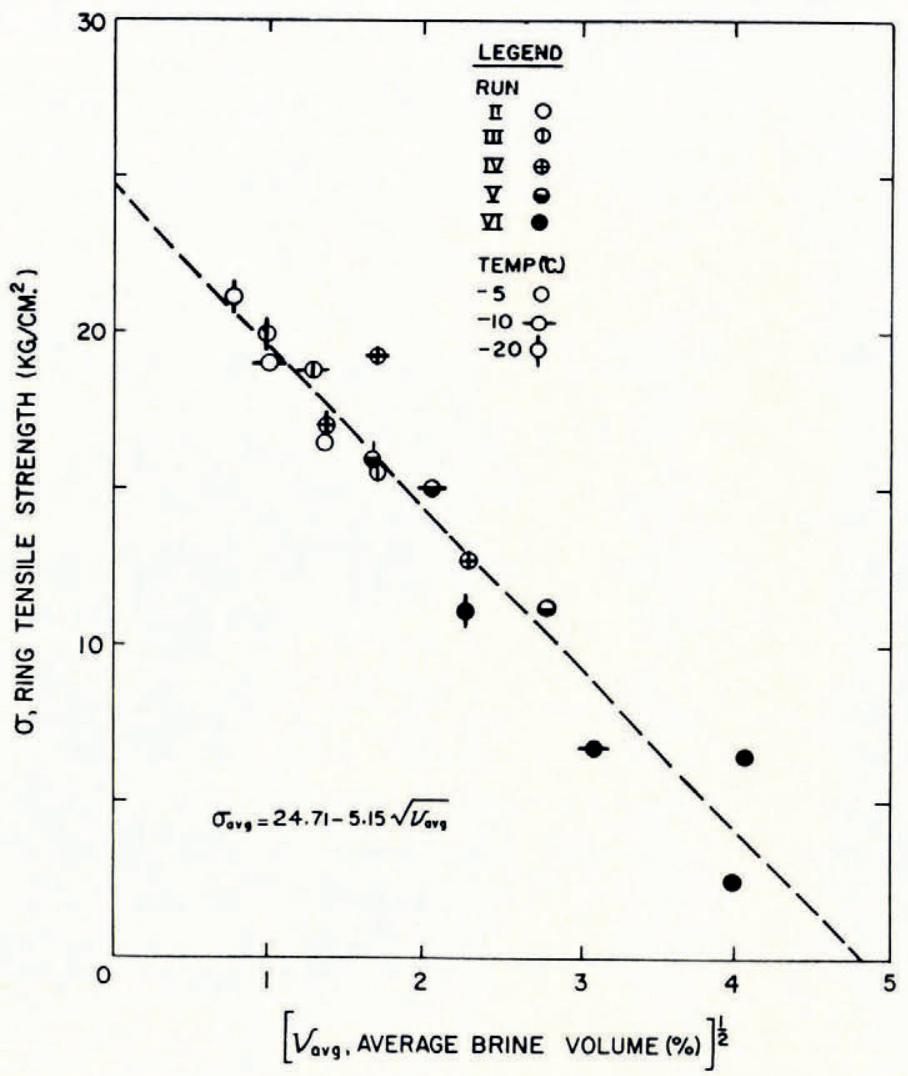

Fig. 16. Average ring-tensile strength vs average $\nu^{1}, T_{1}$ warmer than $-21 \cdot 2^{\circ} \mathrm{C}$.

Table II also gives value of $\nu_{\mathrm{o}}$, the volume of brine in parts per thousand that would cause the ice to have a negligible ring-tensile strength. These values are determined from the intercepts of the $\sigma=f_{l}\left(\nu^{k}\right)$ curves with the $\nu^{k}$ axis. The $\nu_{0}$ intercept taken from the $\sigma_{a v}$ against $\nu_{a v}$ plot is $194 \%$, as compared with $152 \%$ computed by Anderson and Weeks (1958) from petrographic measurements. ice.

6. No evidence was found to support the hypothesis that a phase hysteresis exists in $\mathrm{NaCl}$

7. No evidence was found for the existence of geometric hysteresis in $\mathrm{NaCl}$ ice tested at temperatures above the eutectic point. Therefore the strength of the sample can be considered independent of the specific thermal history immediately before testing. However, the strength of the ice tested at temperatures below the eutectic point was strongly dependent on whether or not the sample had been subjected to temperatures above the eutectic point. The sample groups that had been pulsed to warm temperatures gave strengths appreciably lower than those that were always kept below the eutectic temperature. The decrease in strength is 
proportional to the square root of the volume of brine existing in the ice during the warm portion of the thermal cycle. This phenomenon is termed the "brine redistribution effect".

8. Short term cooling produces an appreciable decrease, approximately 20 per cent, in the tensile strength $\mathrm{cf}$ fresh and $\mathrm{NaCl} \cdot{ }_{2} \mathrm{H}_{2} \mathrm{O}$ ice. This decrease is believed to be the result of thermal shock, which produces microcracks in the ice.

Figure I 7 summarizes the general conclusions of this study as to the strength variation of $\mathrm{NaCl}$ ice. To obtain the relative tensile strength of $\mathrm{NaCl}$ ice, the actual strength is divided by $24.7 \mathrm{~kg} . / \mathrm{cm}^{2}{ }^{2}$, the basic strength of salt ice as determined in this paper. Note that at temperatures between approximately $-10^{\circ}$ and $-2 \mathrm{I} \cdot 2^{\circ} \mathrm{C}$., the ice strength is relatively insensitive to temperature changes, while at temperatures above $-10^{\circ} \mathrm{C}$., the strength decreases rapidly with rising temperature.

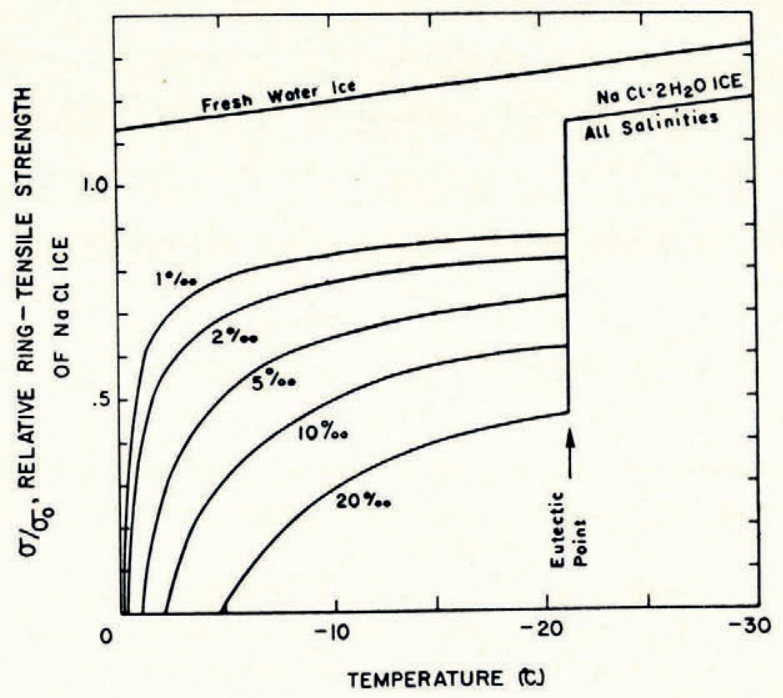

Fig. 17. Relative ring-tensile strength of $\mathrm{NaCl}$ ice as a function of temperature and salinity

Sea ice

The results presented in this paper permit an experimental evaluation of certain aspects of the different hypotheses of Assur (1958) concerning the variation of the strength of natural sea ice. Points of interest are as follows :

I. The strength of fresh-water ice obtained in the laboratory and reported in this paper is considerably higher than the strength of natural fresh-water ice as assumed by Assur.

The strength of fresh-water ice should, therefore, be considered as a limit which is approached but is apparently not exceeded by the strength of very cold sea ice.

2. The slopes and intercepts of the $\sigma_{a v} v s \nu_{a v}^{\ddagger}$ plots are apparently quite different in the temperature range where only ice and brine co-exist (temperatures above $-8 \cdot 7^{\circ} \mathrm{C}$. for normal sea ice and $-2 \mathrm{I} \cdot 2^{\circ} \mathrm{C}$. for $\mathrm{NaCl}$ ice).

Because of limited data, Assur (1958, Fig. I7, p. 131) calculated the value of $\nu_{\mathrm{o}}$, his $B_{\mathrm{o}}$, by substituting assumed petrographic data into his equation for an elliptical brine pocket model. The line $\sigma_{0}-v_{0}$ was then fitted by least squares using only the data with $v_{a v}^{\ddagger}$ values $\leqslant$ 3.0 when $\nu$ is expressed in per cent. Tests with $\nu_{a v}^{k}>3.0$ were interpreted as showing a rapid increase in strength with small changes in $\nu$ and were considered separately. Therefore, the line $\sigma_{\mathrm{o}}-\nu_{\mathrm{o}}$ is essentially determined by two points; $\nu_{\mathrm{o}}$, which was assumed, and the mean ratio of the $\sigma_{a v}$ and $\nu_{a v}^{\ddagger}$ values. The slope of the least-squares line is relatively independent of the actual slope of a line fit only to the test results and depends mainly upon the position of $\nu_{\mathrm{o}}$. The intercepts of this line are given in Table II. 
The strength tests on $\mathrm{NaCl}$ ice, however, indicate that $\sigma_{a v}=f_{l}\left(v_{a v}^{\frac{1}{u}}\right)$ apparently plots as a continuum and does not show a rapid decrease in strength at $\nu^{\frac{1}{2}}$ values $\geqslant 3 \cdot 0$ (Fig. I6). That a similar interpretation is also in agreement with the test results from sea ice has been shown by Assur's empirical analysis (1958; p. 128-130). This is rather surprising since Assur has shown from theoretical considerations that if $\sigma$ varies with $\nu^{\frac{1}{2}}$, a rapid decrease in strength

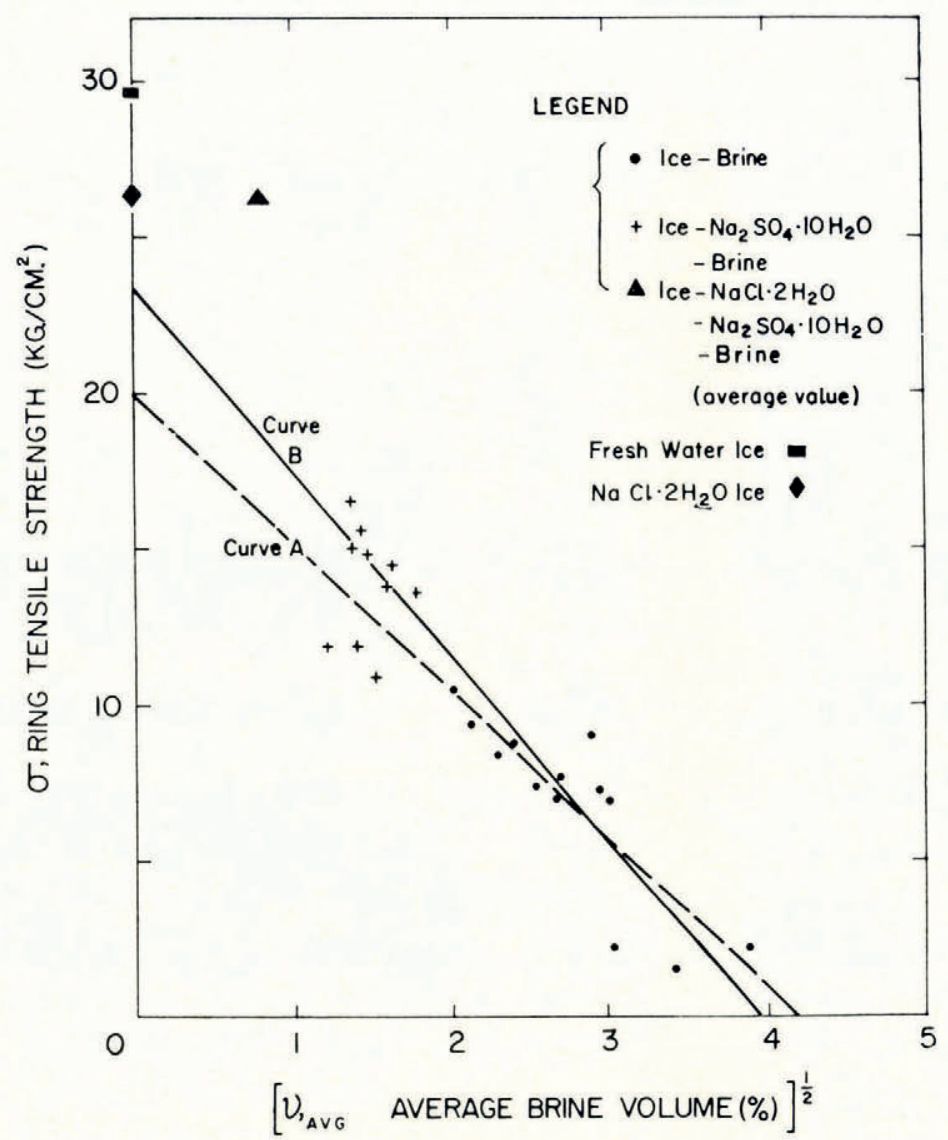

Fig. 18. Measured tensile strength of sea ice vs the square root of the relative volume of brine (after. Assur, 1958)

at high brine volumes is necessary. Also, the sharp demarcation between the strengthless "skeleton layer" at the bottom of a growing ice sheet and the overlying ice indicates that such an interpretation is reasonable. Perhaps the difference is the result of the fact that the high brine volumes studied in the present paper were obtained by high salinities while, in the field, high brine volumes are produced by temperatures near the melting point. This problem definitely merits further study.

Figure 18 shows a plot of Assur's data for normal sea ice (Assur, 1958, table 4, p. 1 29), tested in the temperature range of the ice-brine system (dots). Curve $\mathrm{A}$ is a least-squares fit of these tests $\left[\sigma_{a v}=19 \cdot 9 \mathrm{I}-4.75 v_{a v}^{b}\right]$. The $\sigma_{\mathrm{o}}$ and $\nu_{\mathrm{o}}$ values are now $19.9 \mathrm{I} \mathrm{kg} . / \mathrm{cm} .^{2}$ and $175 \%$ respectively, which are in the range of the values reported in this study.

3. Assur has hypothesized that the crystallization of solid $\mathrm{Na}_{2} \mathrm{SO}_{4} \cdot \mathrm{IOH}_{2} \mathrm{O}$ in sea ice at temperatures between $-8 \cdot 7^{\circ}$ and $-22 \cdot 9^{\circ} \mathrm{C}$. causes the strength to become roughly one-third 
greater than would be expected if only brine were present in the icc. At temperatures below $-22 \cdot 9^{\circ} \mathrm{C}$., the crystallization of $\mathrm{NaCl} \cdot{ }_{2} \mathrm{H}_{2} \mathrm{O}$ may cause an even greater increase in the strength of the ice.

Figure 18 shows that sea-ice strengths determined in the temperature range of an icebrine- $\mathrm{Na}_{2} \mathrm{SO}_{4} \cdot \mathrm{IOH}_{2} \mathrm{O}$ system (crosses) appear to lie on the extension of Curve A. Curve B is a least squares fit of all the data tested at temperatures above $-22.9^{\circ} \mathrm{C}$., $\sigma_{a v}=23.40-$ $5 \cdot 91 v_{a v}^{t}$, excluding the three low values of $\mathrm{Na}_{2} \mathrm{SO}_{4} \cdot 10 \mathrm{H}_{2} \mathrm{O}$ ice. These three points appear to be unusually low in both Assur's and the present analysis. Curve B is also in reasonable agreement with the curve determined for $\mathrm{NaCl}$ ice. Which of these curves, $\mathrm{A}$ or $\mathrm{B}$, most closely represents the $\sigma=f_{l}\left(v^{\frac{1}{2}}\right)$ function for an ice-brine sea ice system is impossible to decide at the

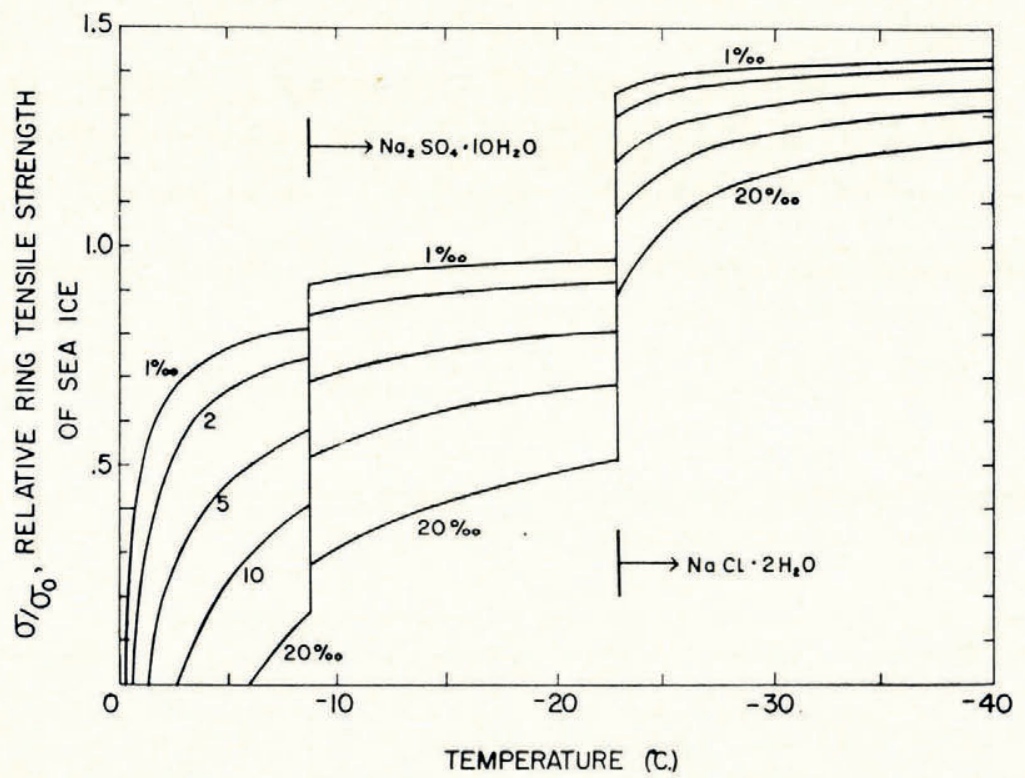

Fig. 19. Tentative diagram showing the relative ring-tensile strength of sea ice as a function of temperature and salinity. Assuming curve $A$ (Fig. 18$)$ for the $\sigma=f_{l}\left(v^{\natural}\right)$ relationship

present. If Curve $\mathrm{A}$ is chosen, it may be hypothesized that the crystallization of $\mathrm{Na}_{2} \mathrm{SO}_{4}$. $\mathrm{IOH}_{2} \mathrm{O}$ causes a strength increase of approximately 20 per cent. If Curve B is used, there is no evidence for a strength increase. In any case, it appears that the effect of $\mathrm{Na}_{2} \mathrm{SO}_{4} \cdot \mathrm{IOH}_{2} \mathrm{O}$ on the strength of the ice, if it exists, is less than originally assumed by Assur. At the present time, ring-tensile tests are being performed on ice from the system $\mathrm{NaCl}-\mathrm{Na}_{2} \mathrm{SO}_{4}-\mathrm{H}_{2} \mathrm{O}$ in an attempt to resolve this question.

At temperatures below $-22 \cdot 9^{\circ} \mathrm{C}$., where $\mathrm{NaCl} \cdot{ }_{2} \mathrm{H}_{2} \mathrm{O}$ crystallizes, the data presented by Assur are approximately 60 and 40 per cent higher than the values obtained from extrapolating curves A and B (Fig. 18). The average strength of sea ice containing brine is less than the strength of fresh-water ice and similar to the strength of $\mathrm{NaCl} \cdot{ }_{2} \mathrm{H}_{2} \mathrm{O}$ ice, as determined in this paper. Since the strength of salt ice does not seem to exceed the strength of lake ice even when all the brine has solidified, this suggests the hypothesis that the crystallization of $\mathrm{NaCl} \cdot 2 \mathrm{H}_{2} \mathrm{O}$ in natural sea ice affects the ice strength in a manner initially suggested by Assur for $\mathrm{Na}_{2} \mathrm{SO}_{4}$. ${ }_{1} \mathrm{OH}_{2} \mathrm{O}$. The solid salt reinforces the brine pockets, but does not cause an appreciable change in Young's modulus of the bulk sample, producing a discontinuity in the strength at $-22 \cdot 9^{\circ} \mathrm{C}$. This reinforcement would be independent of the amount of precipitated $\mathrm{NaCl} \cdot{ }_{2} \mathrm{H}_{2} \mathrm{O}$, provided that a certain critical amount has been precipitated. At temperatures below $-22 \cdot 9^{\circ} \mathrm{C}$., 
the ring-tensile strength should continue to increase as a linear function of $\left(\mathrm{I}-\nu^{\frac{1}{2}}\right)$ approaching the strength of fresh-water ice or slightly below as a limit as the reduction of brine volume causes an increase in the effective cross-section.

Figure I9 shows a possible interpretation of the relative tensile strength $\left(\sigma / \sigma_{\mathrm{o}}\right)$ of sea ice as a function of temperature and salinity, if curve A (Fig. I8) is assumed to be the correct curve for the $\sigma=f_{l}\left(\nu^{\frac{1}{2}}\right)$ relation when only ice and brine coexist. The curves showing the influence of $\mathrm{Na}_{2} \mathrm{SO}_{4} \cdot \mathrm{IOH}_{2} \mathrm{O}$ and $\mathrm{NaCl} \cdot{ }_{2} \mathrm{H}_{2} \mathrm{O}$ were drawn parallel to curve $\mathrm{A}$, but with the appropriate discontinuities. Figure 20 shows a possible interpretation, if curve $\mathrm{B}$ is assumed to be the correct curve. In this case, no increase in strength is attributed to the crystallization of $\mathrm{Na}_{2} \mathrm{SO}_{4} \cdot{ }_{1} \mathrm{H}_{2} \mathrm{O}$. Both figures, of course, are highly schematic.

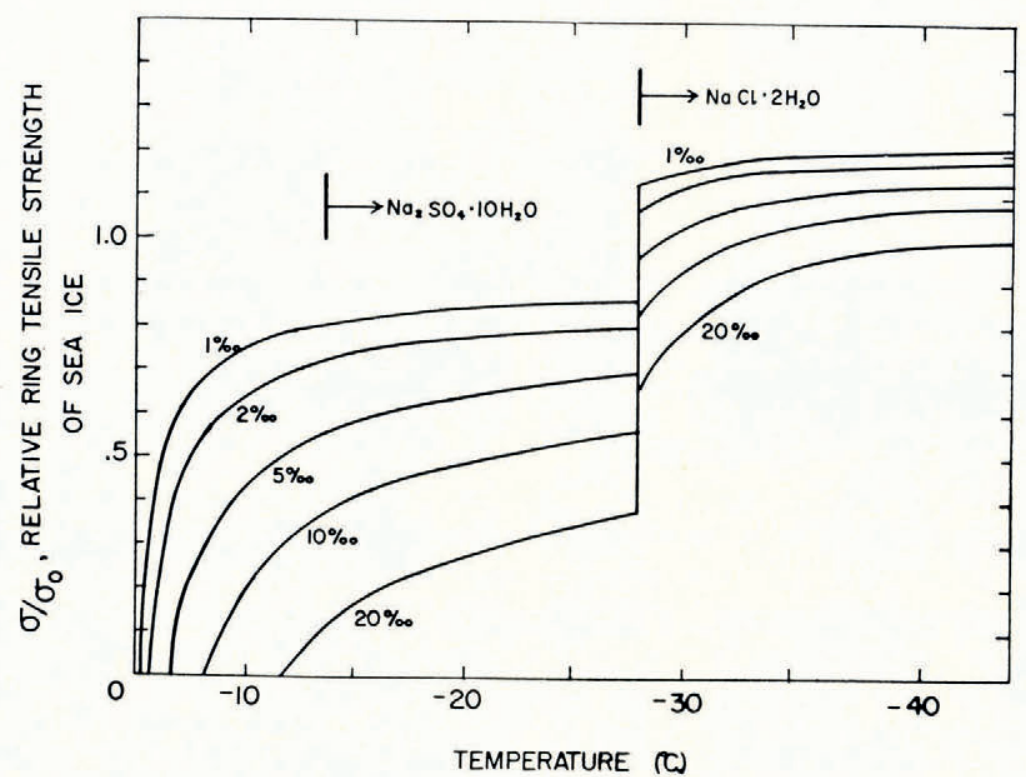

Fig. 2o. Tentative diagram showing the relative ring-tensile strength of sea ice as a function of temperature and salinity. Assuming curve $B$ (Fig. $\left.{ }_{1} 8\right)$ for the $\sigma=f_{i}\left(\nu^{1}\right)$ relationship

Another possibility is that the crystallization of $\mathrm{NaCl} \cdot{ }_{2} \mathrm{H}_{2} \mathrm{O}$ increases the strength of sea ice to the strength of $\mathrm{NaCl} \cdot{ }_{2} \mathrm{H}_{2} \mathrm{O}$ ice, and, after a certain amount of $\mathrm{NaCl} \cdot{ }_{2} \mathrm{H}_{2} \mathrm{O}$ has crystallized, the strength does not vary with changes in the remaining volume of brine. In this case, the lower temperature curves in Figures 19 and $20\left(T<-22 \cdot 9^{\circ}\right.$ C.) would be similar to the relations shown in Figure $\mathrm{I} 7$ at temperatures below $-2 \mathrm{I} \cdot 2^{\circ} \mathrm{C}$. Because of the extremely high scatter in ring-tensile tests made on sea ice at temperatures below the $\mathrm{NaCl} \cdot{ }_{2} \mathrm{H}_{2} \mathrm{O}$ crystallization point, these two interpretations may be difficult to resolve from field tests.

Petrographic measurements under controlled thermal conditions have been made on a large number of thin sections of $\mathrm{NaCl}$ ice in order to determine the specific relations between brine-pocket geometry, ring-tensile strength, and the conditions prevailing during the growth of the ice sheet. Also, a large number of additional ring-tensile tests have been completed, using ice obtained from freezing solutions in the systems $\mathrm{Na}_{2} \mathrm{SO}_{4}-\mathrm{H}_{2} \mathrm{O}$ and $\mathrm{Na}_{2} \mathrm{SO}_{4}-\mathrm{NaCl}-$ $\mathrm{H}_{2} \mathrm{O}$. The results of these studies will appear later.

\section{Acknowledgements}

This paper was written as part of an investigation supported by the Snow and Ice Basic Research Branch; Snow, Ice and Permafrost Research Establishment, U.S. Army Corps of 
Engineers. The experimental work was carried out in the SIPRE laboratories, Wilmette, Illinois. W. F. Moll, G. Walker and R. Klaub assisted the author during the experimentation. T. R. Butkovich, C. C. Langway, J. Bender and Dr. H. Bader provided the author with many valuable: gestions. In particular, the author would like to thank Dr. A. Assur for his stimulating discussions of problems relating to sea-ice strength and for critically reading and helping to clarify many points in the final manuscript.

\section{MS. received 1.9. Jamuary 1961}

\section{REFERENCES}

Adams, I. H and Gibson, R. E 1930. The melting curve of sodium chloride dihydrate: an experimental study of an incongruent melting at pressures up to twelve thousand atmospheres. Fournal of the American Chemical Society, Vol. 52, No. I I, p. $4252-64$.

Anderson, D. L. 1960 . The physical constants of sea ice. Research, Vol. ${ }_{13}$, No. 8, p. $310-18$.

Anderson, D. L., and Weeks, W. F. 1958. A theoretical analysis of sea ice strength. Transactions. American Geophysical Union, Vol. 39 , No. 4, p. 632-40.

Assur, A. 1958. Composition of sea ice and its tensile strength. (In Arctic sea ice. Washington, D.C., p. 106-38. ([U.S.] National Academy of Sciences - National Research Council Publication 598.))

[Bader, H.] 1957. Ice drills and corers. Journal of Glaciology, Vol. 3, No. 2 1, p. 30.

Butkovich, T. R. I 954. Ultimate strength of ice. U.S. Snow, Ice and Permafrost Research Establishment. Research Paper I I.

Butkovich, T. R. 1955. Density of single crystals of ice from a temperate glacier. Journal of Glaciology, Vol. 2, No. 18, p. $553-59$.

Butkovich, T. R. 1956. Strength studies of sea ice. U.S. Snow, Ice and Permafrost Research Establishment. Research Report 20.

Butkovich, T. R. 1958. Recommended standards for small-scale ice strength tests. Transactions of the Engineering Institute of Canada, Vol. 2, No. 3, p. 1 I 2-15.

Butkovich, T. R. I959[a]. Some physical properties of ice from the TUTO tunnel and ramp, Thule, Greenland. U.S. Snow, Ice and Permafrost Research Establishment. Research Report 47.

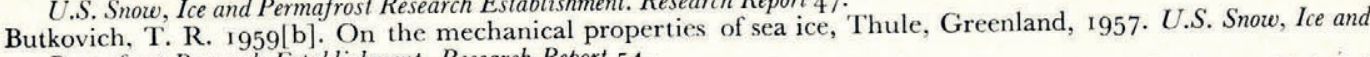
Permafrost Research Establishment. Research Report 54.

Frankenstein, G. 1959. Strength data on lake ice. U.S. Snow, Ice and Permafrost Research Establishment. Technical Report 59 .

Goulden, C. H. 1952. Methods of statistical analysis. Second edition. New York, Wiley and Sons.

Hitch, R. D. 1959. Flexural strength of clear lake ice. U.S. Snow, Ice and Permafrost Research Establishment. Technical

Report 65.
Jellinek, H. H. G. 1958. The influence of imperfections on the strength of ice. Proceedings of the Physical Society (London), Vol. 71, Pt. 5, p. 797-814.

Landolt, H. H., and Börnstein, R. 1936. Physikalisch-chemische Tabellen. 5 Aufl., 3 Ergänzungsband, 3 Teil. Berlin, J. Springer.

Langleben, M. P. 1959. Some physical properties of sea ice. II. Canadian Journal of Physics, Vol. 37, No. 12, p. 1438-

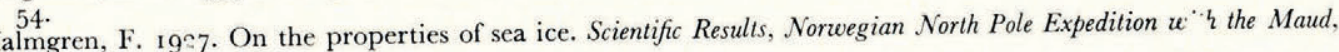
1918-1925, Vol. 1 , No. 5 .

Pounder, E. R., and Little, E. M. 1959. Some physical properties of sea ice. I. Canadian Journal of Physics, Vol. 37,

No. 4, p. 443-73.
Ringer, W. E. 1906 . Deveranderingen in samenstelling van zeewater bij het bevriezen. Chemisch Weekblad, Vol. 3 ,

1906, p. 223-49.
Ripperger, E. A., and Davids, N. 1947. Critical stresses in a circular ring. Transactions of the American Society of Civil Engineers, Vol. 112, p. 6r9-35.

Thompson, T. G., and Nelson, K. H. 1956. Concentration of brines and deposition of salts from sea water under frigid conditions. American fournal of Science, Vol. 254, No. 4, p. 227-38.

Vogel, A. I. 1952. Text-book of quantitative inorganic analysis. Second edition. London, Longmans, Green and Co.

Weeks, W. F., and Anderson, D. L. 1958. An experimental study of strength of young sea ice. Transactions. American Geophysical Union, Vol. 39, No. 4, p. 641-47.

Wilson, J. T., and Horeth, J. M. 1948. Bending and shear tests on lake ice. Transactions. American Geophysical Union, Vol. 29, No. 6, p. 909-12.

Zubov, N. N. 1945. L'dy arktiki. Moscow, Izdatel'stvo Glavsevmorputi. 